\title{
Análise Tomográfica e Histomorfométrica Comparativa entre Enxerto Ósseo Autógeno e Enxerto Ósseo Xenogênico em Cirurgia de Levantamento de Seio Maxilar em Coelhos
}

CRISTINA MIGUEL SICCA

\begin{abstract}
Dissertação apresentada à Faculdade de Odontologia de Bauru, Universidade de São Paulo, para obtenção do grau de Mestre em Odontologia - área Biologia Oral.
\end{abstract}

(Edição Revisada)

Orientador: Prof. Dr. José Mauro Granjeiro 

Sicca, Cristina Miguel

Si12a Análise tomográfica e histomorfométrica comparativa entre enxerto ósseo autógeno e enxerto ósseo xenogênico em cirurgia de levantamento de seio maxilar em coelhos / Cristina Miguel Sicca. - Bauru, 2005.

$61 \mathrm{p} .:$ il.; $31 \mathrm{~cm}$.

Dissertação. (Mestrado) - Faculdade de Odontologia de Bauru. Universidade de São Paulo.

Orientador: Prof Dr José Mauro Granjeiro

Autorizo, exclusivamente para fins acadêmicos e científicos, a reprodução total ou parcial desta dissertação, por processos fotocopiadores e outros meios eletrônicos.

Assinatura: 



\section{CRISTINA MIGUEL SICCA}

Nascimento

Filiação

1996-1999

2001-2003

Associações
$11 / 11 / 1977$

Conchas - SP

Carlos Ivan Sicca

Dalila Miguel Sicca

Curso de Graduação em Odontologia na Faculdade de Odontologia de Bauru, Universidade de São Paulo.

Curso de Especialização em Implantodontia na Associação Paulista de Cirurgiões Dentistas Araçatuba/SP

CRO - Conselho Regional de Odontologia - SP 


\section{AGRADECIMENTOS}

Agradeço aos meus queridos pais pelo apoio, dedicação e exemplo de honestidade e respeito.

Ao meu amor Rodrigo Giovani Camargo pelo amor e companheirismo nestes últimos 4 anos e principalmente pela paciência nos últimos meses.

Ao meu orientador e grande amigo, Prof. José Mauro Granjeiro, pela confiança e estímulo oferecido a mim em todos esses anos de orientação.

Ao Prof. Rumio Taga pelos conhecimentos recebidos e pelo exemplo de grande mestre e acima de tudo extremamente humilde.

Às amigas Tânia e Dani pela paciência e dedicação no auxílio para que fosse possível a realização deste trabalho e pela grande amizade que fizemos.

Aos funcionários do Biotério, Sr. Luis, Sr. Erasmo, Richard e Wagner, por toda dedicação e ajuda imprescindível para a realização da primeira parte deste trabalho.

Aos grandes amigos do Laboratório de Bioquímica e Histologia: Vandinha, Corotti, Juliane, Tati Salles, Rejane, Juliano (Vende Pão), Kati, William, Basílio, Janete, Flávia Loca, Irene, Thaisinha, Tati Furlani. 


\section{SUMÁRIO}

LISTA DE ABREVIATURAS $\ldots \ldots \ldots \ldots \ldots \ldots \ldots \ldots \ldots \ldots \ldots \ldots \ldots \ldots \ldots \ldots \ldots \ldots$

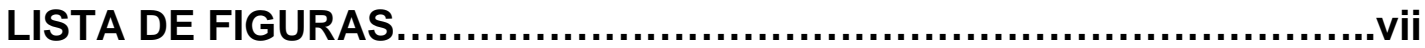

LISTA DE TABELAS

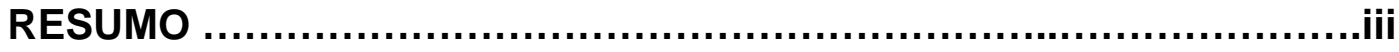

1 INTRODUÇÃO....................................................................

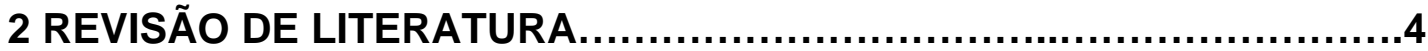

3 PROPOSIÇÃO......................................................... 15

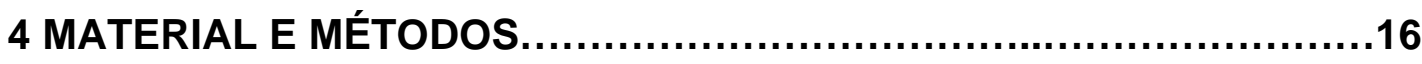

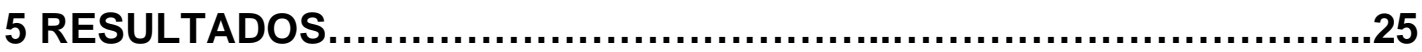

6 DISCUSSÃO..............................................................41

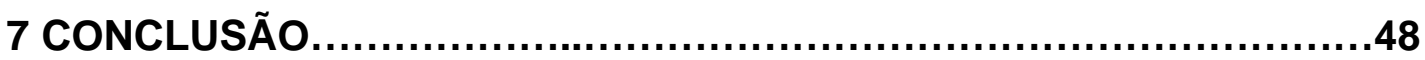

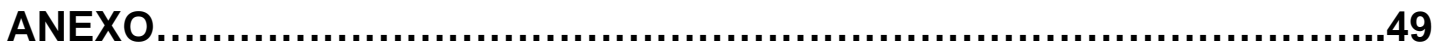

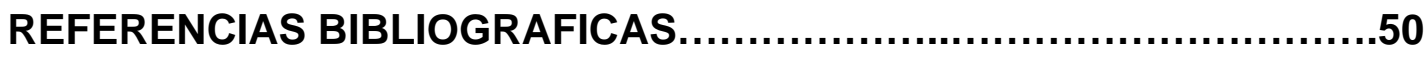

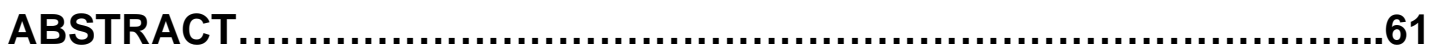




\section{LISTA DE ABREVIATURAS}

BMPs - Proteína morfogenética óssea ou bone morphogenetic proteins

DFDBA - Demineralized freeze-dried bone allografts

EGF - Fator de crescimento epidermal

FDBA - Freeze-dried bone allografts

FGF - Fator de crescimento de fibroblasto

HA - Hidroxiapatita

IGF - Fator de crescimento similar à insulina

PDGF - Fator de crescimento derivado de plaquetas

PDGF - Platelet-derived growth factor

TGF- $\beta$ - Transforming growth factor beta

TGF-ß - Fator de crescimento de transformação 


\section{LISTA DE FIGURAS}

FIGURA 1: Procedimento cirúrgico para remoção de enxerto de osso autógeno da crista ilíaca. Incisão (A), afastamento dos tecidos (B), remoção da cortical óssea da região (C-D), coleta do osso autógeno (E) e sutura dos tecidos (F).

FIGURA 2: $\quad$ Cirurgia para acesso ao seio maxilar do animal. Aplicação de anestésico local (A); incisão (B), descolamento do periósteo (C e D); realização da janela lateral para acesso aos seios maxilares (E e F).

FIGURA 3: Preenchimento dos seios maxilares. Colocação do biomaterial Gen-Tech $\circledast$ elevando-se a membrana sinusal com cureta de dentina (A); preenchimento do seio com o biomaterial (B). Colocação do enxerto de osso autógeno (C) e preenchimento da cavidade (D).

FIGURA 4: $\quad$ Tomografia computadorizada em animal do período de 2 (A), 4 (B) e 8 semanas (C). Seio maxilar direito preenchido pelo biomaterial $(*)$ e seio maxilar esquerdo preenchido com osso autógeno $\left(^{*}\right)$.

FIGURA 5: Densidade óptica obtida pela análise tomográfica dos dois grupos experimentais (Enxerto autógeno e Gen-Tech ${ }^{\circledR}$ ) nos períodos de 2, 4 e 8 semanas.

FIGURA 6: $\quad$ Período de 2 semanas. Grupo Controle (A,B e C) e Grupo Teste (D, E e F). Observa-se a neoformação óssea a partir da região adjacente à membrana sinusal (MS) seguindo pelas partículas de osso autógeno (OA) em A e B e pelas partículas de material inorgânico (MI) em D e E. Nota-se em B e E a presença de tecido conjuntivo (TC). Em C aposição de tecido ósseo neoformado (TON) em partícula de OA. Em F, aposição de tecido ósseo neoformado em partícula inorgânica e células do tecido conjuntivo (CTC) nos poros do material. Coloração hematoxilina-eosina. 
FIGURA 7: $\quad$ Grupo Teste no período de 2 semanas. Infiltrado inflamatório (setas) ao redor do material orgânico (MO). Coloração hematoxilina-eosina.

FIGURA 8: $\quad$ Período de 4 semanas. Em A e D, seio maxilar preenchido com osso autógeno e biomaterial, respectivamente. Em B, neoformação óssea (TON) ao redor de partícula de osso autógeno (OA). Em E, tecido ósseo neoformado ao redor de material inorgânico (MI) e células do tecido conjuntivo (CTC) nos poros do material. Em C, presença de osteoclastos (setas) na superfície de tecido ósseo neoformado. Em F, aposição de tecido ósseo neoformado (TON) em partícula de material inorgânico. Coloração hematoxilina-eosina.

FIGURA 9: $\quad$ Período de 8 semanas. Em A observa-se a presença de tecido mielóide (TM) em grande parte da região. Em B, notase, ainda, partículas de osso autógeno (OA) não reabsorvidas e tecido conjuntivo (TC) mais organizado. Em C, presença de tecido ósseo neoformado e tecido mielóide. Em D, presença de tecido mielóide e tecido ósseo neoformado ao redor das partículas, claramente observado em E e F. Células do tecido conjuntivo mais organizado (F) são notadas no interior de poros do matriz inorgânica (E). Coloração hematoxilinaeosina.

FIGURA 10: Gráfico representando a densidade de volume de tecido conjuntivo e/ou tecido de granulação, em porcentagem, dos grupos teste e controle em função dos períodos experimentais.

FIGURA 11: Gráfico representando a densidade de volume de enxerto de osso autógeno, no grupo controle, e biomaterial Gen-Tech®, no grupo teste, em porcentagem, em função dos períodos experimentais.

FIGURA 12: Gráfico representando a densidade de volume de tecido ósseo neoformado, em porcentagem, dos grupos teste e 
controle em função dos períodos experimentais. 


\section{LISTA DE TABELAS}

TABELA 1: Densidade de volume (\%). Grupo: Controle $\ldots \ldots \ldots \ldots \ldots \ldots \ldots \ldots . . \ldots$

TABELA 2: $\quad$ Densidade de volume (\%). Grupo: Teste $\ldots \ldots \ldots \ldots \ldots \ldots \ldots \ldots \ldots . \quad 37$ 


\section{RESUMO}

O objetivo deste trabalho foi avaliar a neoformacão óssea induzida por um xenoenxerto bovino composto comparativamente ao ósseo autógeno, em cirurgias de levantamento de seio maxilar em coelhos. Nesse estudo utilizouse o seio maxilar de 18 coelhos machos, sendo que no seio maxilar esquerdo foi colocado $200 \mathrm{mg}$ de osso autógeno córtico-medular triturado e no seio maxilar direito, o biomaterial, de origem bovina, composto por matriz orgânica cortical e inorgânica medular, "pool" de BMPs e colágeno (GenTech $®$ ). Realizou-se análise tomográfica por tomógrafo computadorizado (TC) para avaliar a densidade óptica comparativamente entre os grupos e períodos experimentais, a histológica descritiva para verificar a resposta tecidual frente aos materiais implantados e a histomorfométrica para obter os dados de densidade de volume de tecido ósseo neoformado, tecido conjuntivo e/ou granulação, material residual e tecido mielóide. Os resultados obtidos pela TC demonstraram densidade óptica cerca de 2 vezes maior no grupo teste. $\mathrm{Na}$ análise histológica observou-se infiltrado inflamatório apenas no período de 2 semanas do grupo teste e exclusivamente ao redor do componente orgânico do biomaterial. Quanto a neoformação óssea, não houve diferença estatisticamente significativa entre os dois grupos experimentais ou ao longo dos períodos, no entanto a área de tecido mielóide foi cerca de 2 vezes maior no grupo controle. Considerando-se os limites do modelo experimental e da técnica empregada podemos concluir que o biomaterial Gen-Tech $®$ é potencialmente indicado como substituto ósseo em cirurgias de levantamento de seio maxilar, uma vez que promove uma neoformação óssea similar à do osso autógeno. 


\section{INTRODUÇÃO}

Um desafio na reabilitação oral com implantes dentários endoósseos é a reabsorção do osso alveolar, devido à perda da dentição natural e falta de estímulo funcional, acentuado pela colocação de próteses mal adaptadas (UEDA et al ${ }^{68}, 2001$ ).

Particularmente na região posterior da maxila a colocação de implantes dentários é dificultada devido à proximidade com os seios maxilares, pois a perda precoce dos molares pode resultar numa redução do volume ósseo vertical e horizontal causando condições anatômicas desfavoráveis para a cirurgia (YILDIRIM et $\mathrm{al}^{86}, 2001$ ). Tem sido proposto que dois fatores contribuem para a perda óssea mais acentuada nessa região: a)a pressão no interior do seio maxilar com conseqüente aumento da atividade osteoclástica junto à membrana sinusal e b)a perda do osso alveolar após a extração dentária (CHAVANAZ $\left.{ }^{11}, 1990\right)$.

Assim, Tatum, em um encontro de Implantodontia em Birmingham, Alabama, em 1976, propôs o procedimento cirúrgico de levantamento de seio maxilar, ou seja, preenchimento parcial desta cavidade por enxerto ósseo autógeno com o objetivo de aumentar a dimensão óssea vertical na região lateral da maxila para possibilitar a colocação de implantes dentários endoósseos. A primeira publicação desta técnica cirúrgica foi feita por BOYNE e JAMES ${ }^{7}$ (1980).

OLSON et $\mathrm{al}^{46}$ (2000) demonstraram uma taxa de sucesso significativamente superior em implantes colocados em áreas maxilares posteriores tratadas por esta técnica cirúrgica, atribuindo isso à possibilidade de utilização de implantes mais longos nessas regiões comparativamente às que não foram tratadas.

Diversos autores demonstraram que a taxa de sucesso nesses casos é superior a 90\%, equivalente a regiões que não necessitaram de enxertos ósseos (RAGHOEBAR et $\mathrm{al}^{51}, 1993$, DAELEMANS et $\mathrm{al}^{13}, 1997$, TONG et $\left.\mathrm{al}^{67}, 1998\right)$.

Entretanto, a grande limitação na aplicação dessa técnica está 
relacionada à obtenção de tecido ósseo autógeno, pois a remoção de enxertos de regiões intra-orais (ramo mandibular, mento, túber da maxila) apresenta desvantagens como uma segunda intervenção cirúrgica e morbidade do local doador (RAGHOEBAR ${ }^{52}$ et al, 2001, JOSHI ${ }^{30}, 2004$ ), além da quantidade de osso autógeno ser limitada (SCHIMMING e $\mathrm{SCHMELZEISEN}^{54}$, 2004). Sua obtenção de áreas extra-orais, como crista ilíaca e calota craniana, apresenta um maior custo, devido à necessidade de internação hospitalar, bem como importante morbidade da região doadora. Em relação a esse fato, salienta-se que aproximadamente $8 \%$ de enxertos obtidos da crista ilíaca resultam em complicações como infecções, perda sanguínea, injúrias em nervos, pós-operatório doloroso e deficiência funcional (YOUNGER e $\operatorname{CHAPMAN}^{88}$, 1989). Esses números são significativos se considerarmos que, apenas nos Estados Unidos da América, foram realizados cerca de 400 mil enxertos ósseos no ano 2000 $\left(\right.$ SERVICE $\left.^{58}, 2000\right)$, o que representaria aproximadamente 32.000 pacientes com seqüelas pós-operatórias.

Em decorrência das dificuldades acima expostas, substitutos ósseos têm sido propostos como alternativas ao enxerto ósseo autógeno em cirurgias ortopédicas e maxilofaciais e, conseqüentemente, para o levantamento de seio maxilar (FUGAZZOTTO e VLASSIS ${ }^{18}, 1998$, VALENTINI e ABENSUR ${ }^{72}$, 2003).

Nas cirurgias de levantamento de seio maxilar, entre os diversos tipos de biomateriais utilizados, os de origem xenogênica têm demonstrado excelente propriedade osteocondutora e resultados promissores (SCHLEGEL et $\mathrm{al}^{55}, 2003$, VALENTINI e ABENSUR ${ }^{72}, 2003$, JOHN e WENZ ${ }^{29}, 2004$; HALLMAN e NORDIN ${ }^{20}, 2004$ ).

No entanto, a despeito da intensa pesquisa nessa área, e do relato de sucesso de diversos materiais, o substituto ósseo ideal ainda não foi obtido. Assim, o osso autógeno continua a ser, para a maioria dos cirurgiões, o material de escolha em função de seu potencial osteogênico e propriedades biomecânicas (MANGANO et a $\left.\right|^{38}, 2003$ ).

Deste modo é importante que testemos vários produtos novos que 
foram recentemente lançados no comércio. Nesse sentido, o Gen-Tech ${ }^{\circledR}$ (Baumer S.A., Mogi Mirim, Brasil, RMS: 103.455.00001) é um biomaterial composto, de origem bovina, que contém matriz orgânica cortical e inorgânica medular, "pool" de BMPs (proteínas ósseas morfogenéticas) e colágeno. Os estudos de cada um desses componentes isoladamente indicaram boa biocompatibilidade (TAGA et $\mathrm{al}^{64}, 1997$; OLIVEIRA et $\mathrm{al}^{45}$; 1999; SICCA et al ${ }^{59}, 2000$; OLIVEIRA et al ${ }^{44}$, 2003), além da matriz orgânica cortical mostrar potencial osteoindutor devido à presença de fatores de crescimento solúveis no seu interior (URIST ${ }^{69}, 1965$; TAGA et al $\left.{ }^{64}, 1997\right)$, da matriz óssea inorgânica medular ter propriedade osteocondutora e física similares à humana $\left(P E E T Z^{48}, 1997\right)$ e o "pool" de BMPs possuir potencial osteoindutor (URIST ${ }^{70}, 1984$; VIANA $\left.{ }^{76}, 2003\right)$. Como o efeito sinergístico desses materiais ainda não está comprovado o objetivo deste trabalho é avaliar o potencial osteogênico deste composto em comparação ao osso autógeno utilizando-se a cirurgia de levantamento de seio maxilar em coelhos como modelo experimental. 


\section{REVISÃO DE LITERATURA}

\subsection{Biomateriais para enxerto ósseo}

Segundo LANE ${ }^{32}$ (1995), os enxertos ósseos podem atuar por 3 tipos de mecanismos: a)osteogênese (crescimento ósseo promovido por osteoblastos transferidos com o enxerto), b)osteoindução (formação de novo osso por novos osteoblastos diferenciados de células mesenquimais indiferenciadas sob a influência de agentes indutores como a BMP e fatores de crescimento) e c)osteocondução (favorecer a proliferação, migração e maturação de osteoblastos e a aposição do osso diretamente sobre o material).

A reconstrução óssea ideal depende, principalmente, da atividade da população de células osteoprogenitoras (OREFFO e TRIFFIT ${ }^{47}, 1999$ ). Entretanto, seu número é limitado e sua ação é dependente de estímulos, como os promovidos por fatores de crescimento. Assim, é necessário encontrar técnicas e materiais que estimulem a sua proliferação e diferenciação para auxiliar no reparo de grandes defeitos ósseos. Atualmente, têm-se utilizado enxertos autógenos, fatores de crescimento e morfogenes, enxertos alógenos, aloplásticos e xenogênicos, isoladamente ou em combinações.

O enxerto autógeno é removido do próprio paciente de regiões extraorais (crista ilíaca e calvária) ou intra-orais (ramo e sínfise mandibular, tuberosidade, toros), dependendo da quantidade de osso necessária. Sua principal vantagem é a transferência de células osteoprogenitoras juntamente com a matriz orgânica e inorgânica (HUNT e JOVANOVIC ${ }^{25}$, 1999), além de ser considerado o enxerto ideal em relação à biocompatibilidade imunogênica e potencial osteogênico (YOSHIKAWA et $\left.\mathrm{al}^{87}, 2004\right)$. No entanto, também apresenta algumas desvantagens como a necessidade de uma segunda intervenção cirúrgica, quantidade limitada, alto risco de reabsorção por ser um enxerto avascular (BURG et $\mathrm{al}^{9}, 2000$ ) e morbidade da área doadora. Assim, por exemplo, no caso de obtenção de enxerto ósseo da crista ilíaca a taxa de complicações, como infecção, perda 
sanguínea, lesão em nervos, deficiência funcional e pós-operatório doloroso, foi relatada em mais de 8\% (YOUNGER e CHAPMAN ${ }^{88}$, 1989). Por outro lado, RAGHOEBAR et $\mathrm{al}^{52}$ (2001) relataram uma taxa de $43 \%$ de parestesia após a remoção de enxerto autógeno da região do mento. Portanto, esses inconvenientes estimulam a procura por outros tipos de materiais.

Por definição, biomateriais substitutos ósseos são compostos utilizados na clínica médica e odontológica que devem auxiliar o reparo ósseo e apresentar biocompatibilidade, previsibilidade, aplicação clínica sem riscos trans-operatórios e seqüelas pós-operatórias mínimas, além de aceitação por parte do paciente. Apesar de não se ter ainda encontrado um material que preencha todos esses requisitos, atualmente já há uma grande variedade de opções que estão em constante desenvolvimento e aperfeiçoamento $\left(\right.$ TAGA $\left.^{63}, 1996\right)$. Esses biomateriais podem ser de origem alógena, xenogênica ou sintética.

O aloenxerto é produzido com ossos de indivíduos da mesma espécie, obtidos de bancos de ossos e processados de tal maneira a preservar a sua propriedade osteoindutora e osteocondutora. Podem ser de 2 tipos, o osso alogênico congelado e liofilizado (FDBA) e o osso alogênico congelado desmineralizado e liofilizado (DFDBA), sendo o segundo mais utilizado pela liberação facilitada de fatores de crescimento e BMPs. Suas principais vantagens são a maior facilidade de obtenção comparativamente ao osso autógeno e a eliminação de um segundo sítio cirúrgico. No entanto, poucas cidades brasileiras possuem banco de ossos, pelo alto custo de manutenção e de um rigoroso controle para impedir a transmissão de doenças e nem sempre a quantidade de tecido disponível em condições ideais supre as necessidades cirúrgicas e a demanda da população. Segundo PRUSS et $\mathrm{al}^{50}$ (2003), podem provocar ainda interação antigênica (resposta imune) e risco de infecção.

Materiais aloplásticos são substitutos ósseos sintéticos disponíveis em textura, tamanho e forma variáveis (MISCH e DIETSH ${ }^{41}$, 1993). Atualmente há um direcionamento nas pesquisas visando a utilização desses materiais, incluindo a hidroxiapatita (HA), fosfato tricálcico e vidro e 
cerâmica bioativos, devido às dificuldades no uso dos enxertos autógenos e alógenos (DUCHEYNE e QIU ${ }^{15}$, 1999).

Ênfase especial tem sido dada ao desenvolvimento de polímeros naturais ou sintéticos. Dentre os naturais, destacam-se o colágeno, fibrina, ácido hialurônico, quitosana, alginato e outros polissacarídeos originados de plantas ou animais (LI e WOZNEY ${ }^{34}$, 2001). Os polímeros sintéticos permitem um melhor controle dos riscos biológicos em relação aos naturais, e das suas propriedades físico-químicas, entretanto, a maioria induz resposta imune/inflamatória após a sua implantação (CANCEDDA et $\mathrm{al}^{10}$, 2003). Os ácidos poliláticos e poliglicólicos são os mais utilizados e têm a vantagem de serem degradados após alguns dias ou anos, dependendo de sua formulação. Uma desvantagem desses materiais é que o mecanismo de degradação leva a diminuição do pH nos tecidos, dificultando a cicatrização local (LI E WOZNEY $\left.{ }^{34}, 2001\right)$.

A HA sintética, no entanto, possui microestrutura e tamanho do cristal muito diferente do osso natural, o que poderia produzir resposta biológica indesejada (STEPHAN $\left.{ }^{60}, 1999\right)$. O osso cortical bovino possui na sua porção inorgânica uma estrutura de HA com porosidade, tamanho, forma e propriedades físicas semelhantes à humana, permitindo um comportamento mais fisiológico durante a regeneração óssea $\left(P E E T Z^{48}, 1997\right)$. Em comparação, a HA sintética é menos flexível o que pode resultar em microfraturas e encapsulamento fibroso (PEETZ48, 1997). A implantação de osso cortical bovino desproteinizado promove resposta tecidual semelhante à implantação de enxerto de osso autógeno ou de osso alógeno mineralizado, o que sugere que pode ser utilizado como material de preenchimento ósseo substituto e como potencial candidato a carreador de BMPs (OLIVEIRA et $\mathrm{al}^{44}, 2003$; VALENTINI e ABENSUR ${ }^{72}, 2003$; JOHN e WENZ ${ }^{29}$, 2004).

O osso bovino inorgânico possui ainda diversas outras vantagens. A microestrutura do cristal de HA é a mesma em todos os vertebrados, portanto removendo-se completamente a porção orgânica e mantendo apenas a estrutura tridimensional de HA consegue-se um carreador 
biocompatível e semelhante à HA natural. Por outro lado, a desmineralização do osso bovino resulta em material constituído principalmente de colágeno tipo I e traços de fatores de crescimento, em particular as BMPs (URIST e STRATES ${ }^{71}$, 1970). Testes realizados mostraram que ambos os materiais produzidos com osso bovino são biocompatíveis (OLIVEIRA et $\mathrm{al}^{45}$, 1999; SICCA et $\mathrm{al}^{59}, 2000$, MARINS et $\left.\mathrm{al}^{39}, 2004\right)$.

Fatores de crescimento, ou moduladores da atividade celular, são peptídeos ou proteínas secretadas que estimulam ou inibem a divisão, diferenciação e migração celular e a expressão gênica. São divididas em super famílias: IGF (fator de crescimento similar à insulina), TGF- $\beta$ (fator de crescimento de transformação), EGF (fator de crescimento epidermal), FGF (fator de crescimento de fibroblasto), PDGF (fator de crescimento derivado de plaquetas), entre outros (LINDSEY $\left.{ }^{35}, 2001\right)$.

Os membros da família TGF- $\beta$ podem ser encontrados em muitos órgãos, mas estão armazenados, principalmente, na matriz óssea e suas funções no reparo ósseo já foram comprovadas (LINDSEY ${ }^{35}$, 2001). As BMPs, glicoproteínas extraídas da matriz óssea desmineralizada pertencentes à família dos TGF- $\beta$, foram descobertas por URIST ${ }^{69}$ em 1965 e desde então mais de 15 já foram relacionadas à capacidade de induzir a formação óssea ectópica (CHENG ${ }^{12}$, 2002). Inicialmente a extração e purificação em larga escala dessas proteínas ósseo-indutoras era dificultada pela necessidade de centenas de quilos de osso bovino para conseguir-se microgramas de BMPs, porém, atualmente, é possível sua produção ampla pela aplicação de técnicas de recombinação genética (LINDSEY ${ }^{35}$, 2001).

A osteogênese obtida pela utilização das BMPs já foi comprovada em diversos trabalhos, porém, como essas proteínas são solúveis in vivo, dispersam-se rapidamente após sua implantação, diminuindo sensivelmente seu efeito osteoindutor no local. Além disso, para a sua ação osteoindutora é necessária também a presença de células precursoras suficientes. Salientase que o número dessas células diminui com a idade, assim recém nascidos possuem cerca de uma célula mesenquimal indiferenciada a cada 10.000 
células da medula óssea, nos jovens a taxa cai para 1 para 100.000, num adulto de 50 anos 1 para 400.000 e 1 para 1 a 2 milhões num adulto de 80 anos (SERVICE $\left.{ }^{58}, 2000\right)$.

Deste modo, em função de suas características, os fatores de crescimento indicados para terapia óssea precisam ser carreados através de um sistema biocompatível, biodegradável e osteocondutor, e que os mantenha pelo tempo necessário no local. Este papel de carreador, potencialmente, pode ser desempenhado pelo osso bovino cortical ou medular, macro ou microgranular, desproteinizado como já foi demonstrado em estudos clínicos (YUKNA et $a^{88}{ }^{88}$ 1998). Além de manter as BMPs no local e fornecer uma estrutura de suporte e de osteocondução, podem também prover um alto conteúdo de cálcio e fósforo, essenciais para a neoformação óssea. 


\subsection{Cirurgia de levantamento de seio maxilar}

O seio maxilar humano no adulto é uma cavidade de formato piramidal situado no crânio, que possui sua base na parede lateral nasal e seu ápice se estendendo até o processo zigomático da maxila. Internamente é revestido por uma mucosa de epitélio tipo respiratório ciliado (membrana Scheneideriana) que é contínua com a mucosa nasal. Esta membrana tem a função de transportar fluidos como pus e muco através do ostium que conecta o seio maxilar com o meato médio da cavidade nasal. A função dos seios maxilares ainda não é totalmente esclarecida. Sugere-se que pode estar relacionada com ressonância vocal, algum grau da função olfatória, aquecimento e umidificação do ar inspirado ou redução do peso do crânio (VAN DEN BERGH et $\mathrm{al}^{74}, 2000$ ).

CHAVANAZ $^{11}$ (1990) propôs que o aumento do seio maxilar ocorre devido à elevação da pressão no interior da cavidade e aumento da atividade osteoclástica de células da membrana sinusal (pneumatização dos seios maxilares). Esse processo juntamente com a perda de osso alveolar após a extração dos dentes posteriores superiores limitam o volume ósseo disponível para a colocação de implantes endoósseos (WADA et al ${ }^{77}$, 2001).

Três principais procedimentos de enxertos ósseos têm sido propostos para o aumento do volume ósseo desta região: a)colocação de enxertos ósseos "inlays" no assoalho do seio maxilar, b)colocação de enxertos ósseos "onlays" no assoalho do seio maxilar para aumentar o volume do rebordo alveolar e c)colocação de enxertos ósseos "inlays" no assoalho do seio maxilar seguido de osteotomia Le Fort I (PIATTELLI et $\mathrm{al}^{49}$, 1999).

Embora diversos tipos de materiais, como o enxerto autógeno, enxerto alógeno, materiais de origem sintética e xenogênica e fatores de crescimento, sejam utilizados em cirurgias de levantamento de seio maxilar, ainda não está claro qual é a melhor opção para esta técnica (TONG ${ }^{67}$ et al, 1998).

O preenchimento dos seios maxilares com enxerto de osso autógeno é utilizado desde 1980 e a colocação de implantes nessas áreas apresenta mais de $90 \%$ de sucesso (BOYNE e JAMES $^{7}, 1980$; TONG et $\mathrm{al}^{67}$, 1998; 
MCCARTHY et $\left.\mathrm{al}^{40}, 2003\right)$. Entretanto, apresentam algumas desvantagens na sua utilização, como uma segunda intervenção cirúrgica, morbidade do local doador e maior custo.

O osso alógeno desmineralizado possui propriedade osteocondutora e algumas publicações relatam ter capacidade osteoindutora devido a presença de BMPs em sua matriz (URIST ${ }^{69}, 1965$, REDDI $^{53}, 2001$ ), o que estimulou sua utilização como material alternativo ao osso autógeno, inclusive em cirurgias de levantamento de seio maxilar, obtendo uma taxa de sucesso de até $100 \%$ em um relato clínico utilizando-se 30 áreas enxertadas e a colocação de 69 implantes (VAN DEN BERGH et al ${ }^{75}, 2000$ ). No entanto, o risco de uma resposta imune e a transmissão de doenças infecciosas causa dúvidas quanto a sua utilização (YILDIRIM et al ${ }^{85}, 2000$ ), além de, no Brasil, haver poucos bancos de ossos, o que conseqüentemente limita sua utilização.

Os materiais aloplásticos, como a HA sintética, o sulfato de cálcio e o vidro bioativo, possuem a vantagem de estarem disponíveis em quantidades ilimitadas, porém são biomateriais apenas osteocondutores. No entanto, alguns estudos demonstraram uma alta taxa de sucesso utilizando-se esses biomateriais para o preenchimento de seios maxilares (DE LEONARDIS e PECORA $^{14}, 1999$, MANGANO et $\left.\mathrm{a}^{38}, 2003\right)$.

Por serem materiais apenas osteocondutores, na maioria das vezes são utilizados como complemento ao osso autógeno ou alógeno. TADJOEDIN et al ${ }^{62}$ (2002) verificaram que quando uma alta quantidade de vidro bioativo em relação à quantidade de osso autógeno ou até mesmo a utilização de $100 \%$ de vidro bioativo é realizada, a formação óssea ocorre numa taxa mais lenta comparativamente à utilização somente de osso autógeno, não eliminando, portanto, a cirurgia para remoção de osso autógeno de regiões intra-orais.

A HA de origem sintética também foi utilizada para o preenchimento de seios maxilares, no entanto, comparativamente à HA de origem xenogênica mostrou um menor percentual de neoformação óssea no período de 12 meses (ARTZI et al ${ }^{3}, 2001$ ), além de, em experimento in vitro, não 
demonstrar evidência de sua reabsorção (TAYLOR et $\mathrm{al}^{65}$, 2002).

A HA de origem bovina mostrou boa propriedade osteocondutora no preenchimento de seios maxilares em diversos estudos clínicos (HALLMAN et $\mathrm{al}^{21}$, 2002; VALENTINI e ABENSUR ${ }^{72}$, 2003; HALLMANN e NORDIN ${ }^{20}$, 2004). No entanto, sua reabsorção ocorre de maneira mais lenta comparativamente ao enxerto de osso autógeno, sendo, ainda, detectada após o período de 26 semanas em cabras (HASS et $\mathrm{al}^{23}, 2002$ ) e, em coelhos, notou-se pouca diminuição no conteúdo dos grânulos entre os períodos de 2 a 10 semanas (XU et $\left.\mathrm{al}^{83}, 2004\right)$. Em humanos, foi relatada a presença dos grânulos 9 meses após a cirurgia de levantamento de seio maxilar (HALLMANN et $\mathrm{al}^{21}$, 2002).

A degradabilidade da HA bovina depende de seu processo de produção, sendo menor quanto mais próximo da temperatura de sinterização tenha sido usada na sua desproteinização (LE GEROS et $\mathrm{al}^{33}$, 1995). A HA de baixa degradabilidade poderia ser vantajosa para a manutenção da dimensão da área aumentada com o tempo (HALMANN et $\mathrm{al}^{21}, 2002$ ), pois o biomaterial atuaria como barreira dificultando a re-pneumatização do seio maxilar que ocorre devido à entrada de ar pelo ostium (XU et $\left.\mathrm{al}^{83}, 2004\right)$.

A HA de origem bovina também tem sido utilizada como carreador de fatores de crescimento acrescentando uma capacidade osteoindutora à sua propriedade osteocondutora (TERHEYDEN et $\mathrm{al}^{66}$, 1999). Neste sentido, convém salientar que ALLEGRINI et $\mathrm{al}^{2}$ (2004) demonstraram, em cirurgia de levantamento de seio maxilar em coelhos, uma neoformação óssea $33,34 \%$ maior no grupo preenchido com HA combinada com BMP do que no grupo que continha apenas HA.

A utilização recente do plasma rico em plaquetas (PRP), fonte de diversos fatores de crescimento em cirurgias buco-maxilofaciais, ainda é controversa na literatura. FURST et $\mathrm{al}^{19}$ (2003) demonstraram que o PRP possui diferentes efeitos na osseointegração, não apresentando um efeito superior quando adicionado à $\mathrm{HA}$. Em humanos, relatou-se um aumento de 5 a $10 \%$ de osso neoformado comparado ao mesmo material sem a adição do PRP (WILTFANG et $\mathrm{al}^{81}$, 2003). Em uma recente revisão sistemática, 
WALLACE e FROUM $^{78}$ (2003) concluíram que as evidências são insuficientes para recomendar a utilização do PRP em cirurgias de levantamento de seios maxilares.

Recentemente utilizou-se a técnica de bioengenharia em cirurgias de levantamento de seios maxilares em coelhos a partir de células autógenas de grande capacidade de osteogênese (SCHIMMING e SCHELZEISEN ${ }^{54}$, 2004). Testou-se, comparativamente, o enxerto ósseo autógeno, a rhBMP-2 carreada em esponja de colágeno, e células osteoprogenitoras cultivadas in vitro, sendo verificado que, com 8 semanas, não havia diferenças estatisticamente significativas no volume de osso formado entre os três tratamentos, porém, a maturação óssea do grupo em que foi utilizada a técnica de bioengenharia foi maior do que o grupo rhBMP-2 (UEDA et al ${ }^{68}$, 2001). SCHMELZEISEN et $a^{156}$ (2003) relataram a formação de osso trabecular após 4 meses da cirurgia utilizando-se a engenharia de tecidos em humanos. SCHIMMING e SCHMELZEISEN ${ }^{54}$ (2004) aplicaram esta técnica com células derivadas do periósteo carreadas por um material sintético e 18 pacientes obtiveram resultado satisfatório, no entanto, 8 pacientes necessitaram de enxerto adicional de osso autógeno.

Enquanto diversas técnicas cirúrgicas e tipos de materiais têm sido utilizados no preenchimento dos seios maxilares, existe uma escassez de publicações clínicas controladas sobre o assunto e, nos poucos trabalhos existentes, a amostra de paciente é muito pequena (TONG et al ${ }^{67}, 1998$ ). Deste modo, para um melhor conhecimento dessa técnica cirúrgica são necessários mais estudos clínicos controlados e sistematizados com uma amostra populacional significante que possa alicerçar a sua melhor indicação e aplicação. 


\subsection{A utilização do coelho como modelo experimental}

Macacos e cabras e, mais recentemente, minipigs são utilizados como modelos experimentais em cirurgias de levantamento de seio maxilar, porém a utilização desses animais envolve maior custo e número de amostra limitado, comprometendo a análise estatística dos resultados. A utilização de cães é contra-indicada uma vez que os seios maxilares destes animais são significativamente diferentes dos humanos por não possuírem membrana Scheneideriana e não sofrerem pneumatização (HASS et al ${ }^{24}$, 1998).

Por outro lado, com o uso de coelhos o custo e os procedimentos de anestesia e cirurgia são facilitados devido ao seu menor porte. Além disso, a presença de muitas glândulas serosas em sua membrana sinusal é útil na determinação de ocorrência de sua perfuração durante o procedimento cirúrgico (WATANABE et al ${ }^{79}, 1999$, UEDA et $\mathrm{al}^{68}{ }^{68}$, 2001) e seu ostium é bem definido similar ao humano (WADA et $\mathrm{al}^{77}, 2001$ ).

A realização de cirurgia de levantamento de seio maxilar em coelhos sem perfuração da membrana sinusal foi demonstrada inicialmente por WATANABE et $\mathrm{al}^{79}$ (1999), que utilizando enxerto autógeno, verificou o aumento no volume ósseo nos períodos entre 2 e 4 semanas e entre 4 e 8 semanas. LUNDGREN et $\mathrm{al}^{37}$ (1996) relataram um aumento de volume ósseo entre 6 a 12 meses após enxerto autógeno em humanos. Comparando estes estudos, WATANABE et al ${ }^{79}$ (1999) sugeriram que o período de 2 a 4 semanas em coelhos seria equivalente ao período de 6 a 12 meses em humanos.

Neste modelo experimental proposto por WATANABE et al ${ }^{79}$ (1999), os seios maxilares inferiores do animal foram enxertados, sendo o acesso realizado através de incisão realizada na face lateral do animal, com dissecação dos músculos e cuidado para não lesionar a artéria facial. A adequação deste modelo foi corroborada por outros estudos (WADA et $\mathrm{al}^{77}$, 2001, UEDA et $\mathrm{al}^{68}, 2001$, ALLEGRINI et $\mathrm{al}^{1}, 2003$, ALLEGRINI et $\left.\mathrm{al}^{2}, 2004\right)$.

Os seios maxilares superiores de coelhos para a realização deste procedimento foram utilizados com sucesso por outros autores, neste caso foi realizada apenas uma incisão perpendicular à sutura naso-palatina e o 
descolamento do periósteo (ASAI et $\mathrm{al}^{4}, 2002, \mathrm{XU}$ et al $\left.{ }^{83}, 2004\right)$. 


\section{PROPOSIÇÃO}

Este trabalho visa avaliar comparativamente a neoformacão óssea induzida por enxerto ósseo autógeno e xenoenxerto bovino composto (GenTech $\left.{ }^{\circledR}\right)$ em cirurgias de levantamento de seio maxilar em coelhos.

Os objetivos específicos são:

1. avaliar por tomografia computadorizada a densidade óssea nos grupos e períodos experimentais;

2. avaliar histologicamente a resposta tecidual frente aos dois tipos de enxertos utilizados nos diferentes períodos experimentais;

3. avaliar histomorfometricamente a densidade de volume do enxerto, infiltrado inflamatório, tecido conjuntivo, tecido ósseo e tecido mielóide; 


\section{MATERIAL E MÉTODOS}

Os procedimentos foram realizados de acordo com as normas da ISO 10993-6 e foram aprovados pela Comissão de Ética no Ensino e Pesquisa em Animais da Faculdade de Odontologia de Bauru - USP (Proc. № 19/2003) (ANEXO).

O total de 18 coelhos albinos adultos, machos, pesando entre 3,5 a 4,5 kg, procedentes do biotério da Faculdade de Medicina Veterinária de Botucatu - UNESP foram utilizados. Esses animais foram confinados individualmente em gaiolas de aço no biotério da Faculdade de Odontologia de Bauru - USP e alimentados antes e durante o experimento com ração sólida triturada e água a vontade, exceto nas 12 horas pré-operatórias.

\subsection{Intervenções cirúrgicas}

Os animais inicialmente foram submetidos à sedação com injeção intramuscular de xilazina na dose de $0,28 \mathrm{~mL} / \mathrm{Kg}$ de peso e, após cinco minutos, anestesiados com quetamina na dose de $0,39 \mathrm{~mL} / \mathrm{Kg}$ de peso.

Após a tricotomia na região da face e da crista ilíaca e antissepsia com solução aquosa de polivinilpirrolidona (PVP-I tópico), uma incisão de cerca de $1,5 \mathrm{~cm}$ foi feita na pele sobre a crista ilíaca direita (FIGURA $1 \mathrm{~A}$ ). $\mathrm{O}$ tecido muscular foi então dissecado até a exposição óssea (FIGURA 1 B). Com uma broca trefina de $5 \mathrm{~mm}$ de diâmetro, sob irrigação constante com solução salina fisiológica estéril, foi retirado cerca de $200 \mathrm{mg}$ de osso autógeno cortico-medular (FIGURA 1 C e D). Após a coleta do enxerto autógeno (FIGURA $1 \mathrm{E}$ ), o tecido muscular foi suturado com fio de sutura reabsorvível 5-0 (Vycryl®, Johnson\& Johnson, São Paulo, Brasil) e, em seguida a pele, com fio de sutura de seda 4-0 (Ethicon $\AA$, Johnson\& Johnson, São Paulo, Brasil) (FIGURA 1 F).

Simultaneamente ao procedimento descrito acima, aplicou-se cerca de $1 \mathrm{~mL}$ de anestésico local articaína 4\% com adrenalina 1:100.000 (Articaíne $100 \AA$, DFL, Rio de Janeiro, Brasil) para diminuir o sangramento da região facial (FIGURA $2 \mathrm{~A}$ ) e uma incisão de cerca de $2 \mathrm{~cm}$ foi realizada 
perpendicular à sutura naso-incisal (FIGURA 2 B). Descolou-se o periósteo (FIGURA 2 C e D) e com uma broca trefina de $5 \mathrm{~mm}$ de diâmetro, sob irrigação de solução salina estéril abundante, foi realizada uma janela cerca de $2 \mathrm{~cm}$ abaixo da sutura naso-incisal e $0,5 \mathrm{~cm}$ para lateral de cada lado do animal (FIGURA 2 E e F). Esta janela foi então removida para acesso aos seios maxilares superiores direito e esquerdo.

A membrana sinusal foi delicadamente elevada com a utilização de uma cureta de dentina para prevenir perfuração e para possibilitar o preenchimento com os materiais: 200mg do biomaterial Gen-Tech® (Baumer S.A., Mogi Mirim, Brasil, RMS: 103.455.00001) hidratado com soro fisiológico no seio maxilar superior direito (FIGURA 3 A e B) ou 200mg de osso autógeno previamente triturado no seio maxilar superior esquerdo (FIGURA 3 C e D). Após o preenchimento da cavidade colocou-se sobre a janela membrana de osso cortical bovino reabsorvível (Gen-Derm®, Baumer S.A., Mogi Mirim, Brasil, RMS: 103.455.00007) para prevenir a invasão de outro tecido. A sutura no local foi realizada com fio de seda 4-0. 

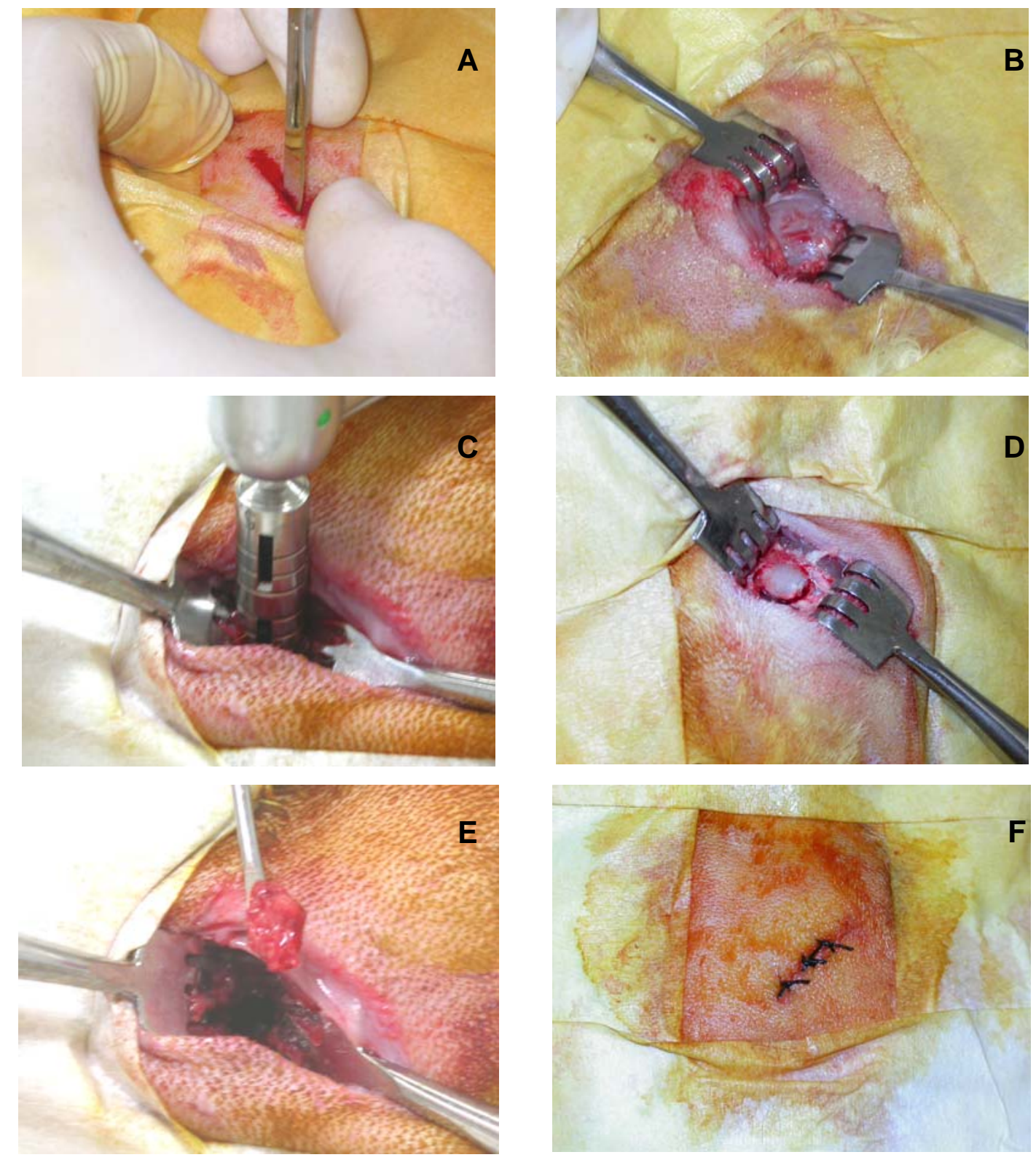

FIGURA 1. Procedimento cirúrgico para remoção de enxerto de osso autógeno da crista ilíaca. Incisão (A), afastamento dos tecidos (B), remoção da cortical óssea da região (C-D), coleta do osso autógeno (E) e sutura dos tecidos $(F)$. 

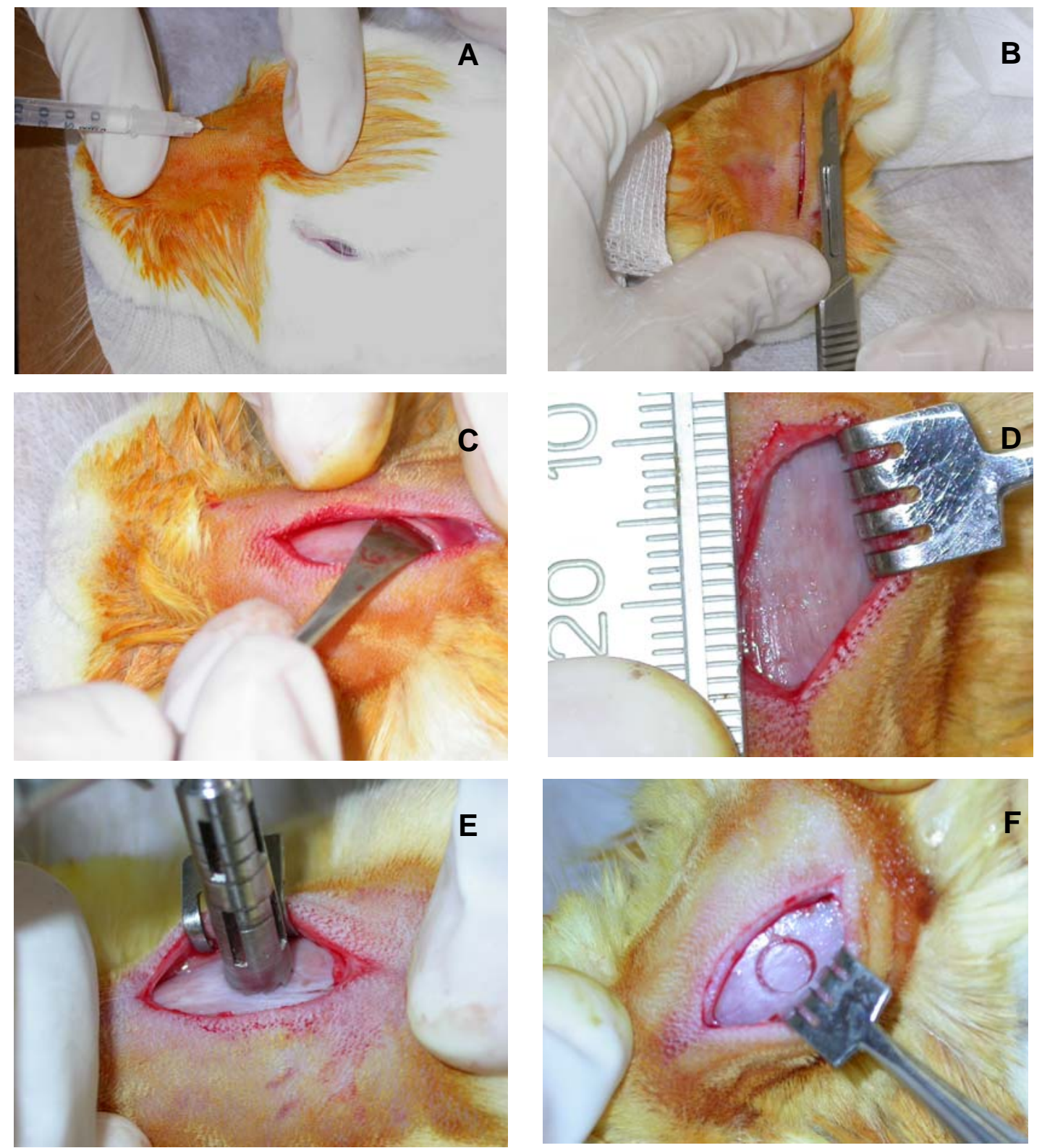

FIGURA 2. Cirurgia para acesso ao seio maxilar do animal. Aplicação de anestésico local (A); incisão (B), descolamento do periósteo (C e D); realização da janela lateral para acesso aos seios maxilares $(E$ e $F)$. 

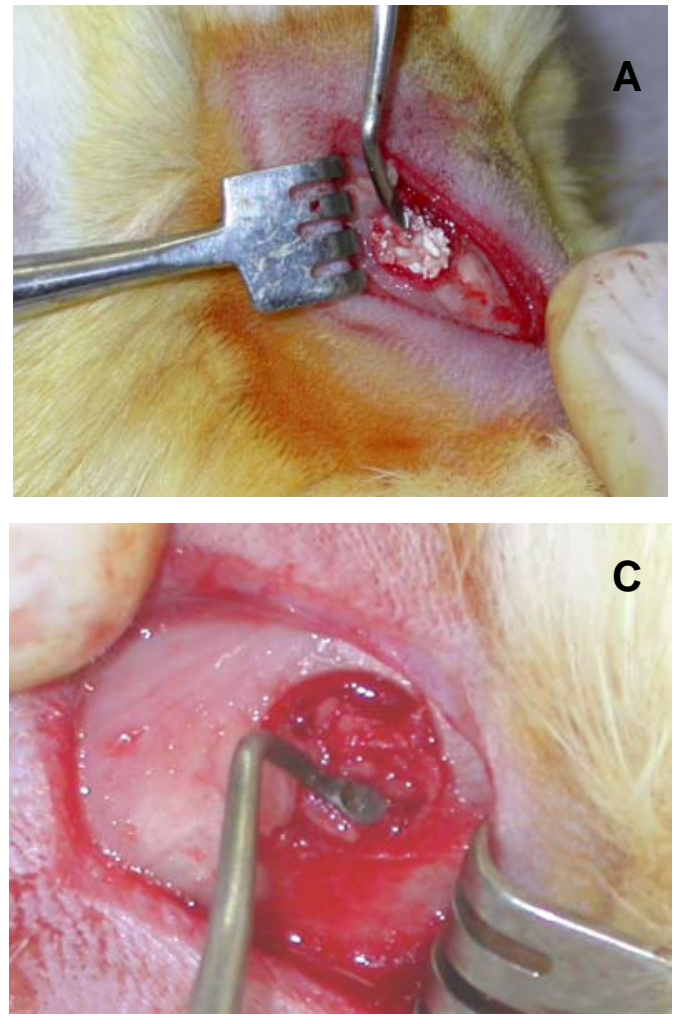

c

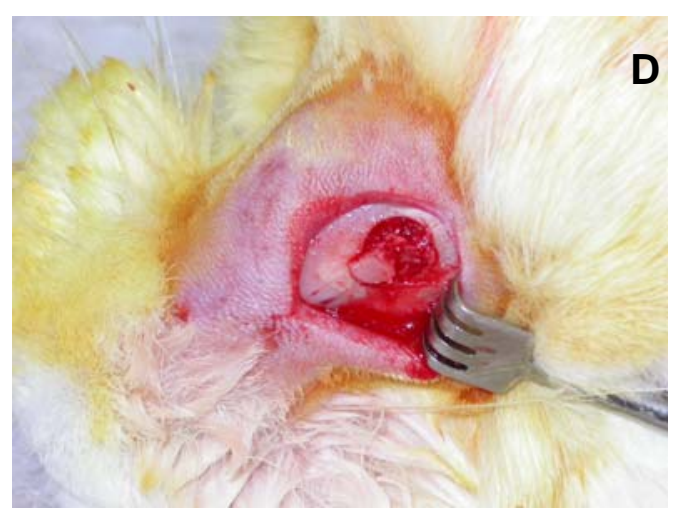

FIGURA 3. Preenchimento dos seios maxilares. Colocação do biomaterial Gen-Tech ${ }^{\circledR}$ elevando-se a membrana sinusal com cureta de dentina $(A)$; preenchimento do seio com o biomaterial (B). Colocação do enxerto de osso autógeno (C) e preenchimento da cavidade (D). 


\subsection{Medicação pós-operatória}

Após a cirurgia aplicou-se, por via intra-muscular, $1 \mathrm{~mL}$ do antibiótico benzilpenicilina benzatina (Pentabiótico Veterinário®; Fort Dodge, São Paulo, Brasil) e $0,2 \mathrm{~mL}$ por $\mathrm{kg}$ de peso de anti-inflamatório ketoprofeno (Ketofen $1 \% ®$, Merial, Brasil). Após 5 dias da cirurgia foi novamente injetado $1 \mathrm{~mL}$ de Pentabiótico veterinário.

\subsection{Obtenção das peças e procedimento histotécnico}

Após os períodos de 2, 4 e 8 semanas, os animais foram previamente submetidos à anestesia com a mistura de xilamina e quetamina na dose de $1 \mathrm{~mL} / \mathrm{Kg}$ para posterior morte por injeção cardíaca de cloreto de potássio a 19\% de acordo com a resolução número 714 do Conselho Federal de Medicina Veterinária. A amostra foi então fixada em formalina 10\% em tampão fosfato $\mathrm{pH}$ 7,2 por uma semana.

Após a realização das tomografias computadorizadas, as peças foram lavadas em água corrente por 24 horas e colocadas em solução de citrato de sódio a $20 \%$ e ácido fórmico a $50 \%$ em partes iguais $\left(M_{0 R S E}^{42}, 1945\right)$ por 48 horas. Foram lavadas novamente por 12 horas e colocadas em solução de EDTA (solução contendo 4,13\% de Tritriplex III Merck® e 0,44\% de Hidróxido de sódio) com trocas a cada 48 horas até sua completa desmineralização.

As peças foram submetidas ao procedimento padrão do laboratório de Histologia da FOB/USP:

a) lavagem em água destilada por 24 horas;

b) banho em etanol $70 \%$ por 48 horas;

c) início do processo de desidratação em etanol a 80\% por 1 hora;

d) banho de uma hora em etanol a $90 \%$;

e) banho de uma hora em etanol a 95\%;

f) dois banhos de uma hora em etanol a 100\%;

g) banho de etanol a $100 \%$ durante 24 horas;

h) início do processo de diafanização em xilol histológico (Merck Co.) por 30 minutos 
i) 2 banhos de uma hora em xilol;

j) banho em Histosec (parafina + resina sintética - Merck Co.) liquefeita em estufa a $60^{\circ} \mathrm{C}$ por uma hora;

k) banho em Histosec liqüefeita por 4 horas;

l) inclusão em Histosec liqüefeita;

m) cortes alternados de $5 \mu \mathrm{m}$ de espessura, foram obtidos em um micrótomo Jung-Leica RM2045 e corados pela técnica da Hematoxilina-Eosina $\left(\operatorname{LUNA}^{36}, 1968\right)$.

\subsection{Análise da densidade óssea por tomografia computadorizada}

As tomografias computadorizadas foram realizadas no Hospital do Câncer A C Camargo da cidade de São Paulo em um tomógrafo Spiral Hi Speed (General Eletric). A espessura dos cortes foi de $1 \mathrm{~mm}$ com intervalo de reconstrução de $0,5 \mathrm{~mm}$ e tempo por rotação de 1 segundo. Utilizou-se filtro para osso.

Os dados obtidos foram comparados, entre os diferentes grupos e diferentes períodos experimentais, pela análise de variância (ANOVA) e contraste de média utilizando-se do software Sigma Stat (Jandel Scientific) para Windows, com um nível de significância de 5\%.

\subsection{Análise histológica descritiva}

Os cortes histológicos foram examinados em um microscópio binocular Axioskop 2 (Carl Zeiss). Na análise microscópica avaliou-se a ocorrência dos seguintes eventos:

a) presença de infiltrado inflamatório;

b) presença de tecido conjuntivo e/ou granulação;

c) reabsorção dos materiais;

d) neoformação óssea;

e) presença do material enxertado.

As fotomicrografias foram obtidas em um fotomicroscópio composto de um microscópio Axioskop (Zeiss) e câmera fotográfica e software MC200 chip. O aumento final da fotografia foi obtido a partir do aumento da objetiva 
x aumento da projetora (10x) x aumento da câmera fotográfica para $35 \mathrm{~mm}$ $(0,32 x) x$ aumento da ampliação fotográfica $(4,26 x)$. (LUNA $\left.{ }^{36}, 1968\right)$.

\subsection{Análise histomorfométrica}

\subsubsection{Casualização dos campos microscópicos}

Todos os métodos estereológicos são baseados em princípios geométricos estatísticos, derivados da probabilidade em que imagens da estrutura na secção histológica coincidam com um sistema-teste apropriado. Deste modo, o ponto central nesses métodos está na casualização das amostras, ou seja, a escolha das amostras do tecido a serem confrontadas com o sistema-teste, deve ser realizada por um método que elimine a ocorrência de vício na amostragem. Isto é conseguido pela aplicação de procedimento de casualização em todos os estágios do experimento, desde a escolha dos animais, a seleção dos blocos histológicos em cada lâmina e, principalmente, a seleção dos campos microscópicos a serem utilizados nas quantificações.

De cada peça histológica foram obtidas 6 lâminas contendo 3 cortes semi-seriados cada uma. Por meio de sorteio foram escolhidas 3 lâminas para serem utilizadas e de cada lâmina selecionado um 1 corte histológico.

Para a escolha dos 20 campos microscópicos por corte, utilizamos um esquema de casualização sistemática segundo as indicações de WEIBEL ${ }^{80}$ (1969). Salientamos que nesse esquema os campos microscópicos foram escolhidos em intervalos regulares, de maneira que todas as regiões do corte histológico foram representadas.

\subsubsection{Avaliação da densidade de volume}

A densidade de volume é definida como a fração de área do todo (enxerto + tecido reacional) ocupada por um determinado constituinte do todo (enxerto, infiltrado inflamatório tecido conjuntivo, tecido ósseo e tecido mielóide) foram avaliados com uma objetiva de imersão de 100X e um retículo de integração II Zeiss colocado em uma ocular Kpl 8X, composta de 
10 linhas paralelas e 100 pontos numa área quadrangular. A imagem do retículo foi superposta sucessivamente a 60 campos histológicos escolhidos por amostragem sistemática (WEIBEL $\left.{ }^{80}, 1969\right)$ e os seguintes dados foram anotados o número de pontos que caíram sobre cada constituinte e sobre a loja cirúrgica inteira. Calculamos a densidade de área de cada constituinte.

\subsubsection{Análise estatística}

Todos os resultados morfométricos foram comparados pela análise de variância (ANOVA) e contraste de médias entre os diferentes períodos e grupos experimentais, utilizando-se do software Sigma Stat (Jandel Scientific) para Windows, com um nível de significância de 5\%. As densidades de área foram submetidas a análises estatísticas após transformação arco-seno dos dados originais. 


\section{RESULTADOS}

\subsection{Análise tomográfica}

A FIGURA 4 mostra, para ilustração, tomografia computadorizada da cabeça de um animal de cada período experimental. A análise das tomografias dos animais nos dois grupos mostrou nos 3 períodos experimentais maior densidade óssea nos seios maxilares preenchidos com o biomaterial.

O gráfico da FIGURA 5 representa a variação na intensidade de densidade óssea, pela escala H.U., em função dos períodos experimentais. Podemos observar que a máxima densidade ocorreu no período de 4 semanas para ambos os grupos, mas diminuiu no autógeno enquanto manteve-se constante no biomaterial.

Comparando-se os períodos experimentais de cada grupo, constatouse diferenças estatisticamente significativas $(p<0,001)$ no grupo controle, entre 2 e 4 semanas e 4 e 8 semanas, não havendo diferença $(p>0,05)$ entre 2 e 8 semanas. No grupo teste, diferenças estatisticamente significativas ocorreram apenas entre 2 e 4 semanas $(p<0.001)$ e 2 e 8 semanas $(p<0,01)$, não havendo diferenças entre 4 e 8 semanas $(p>0,05)$. 

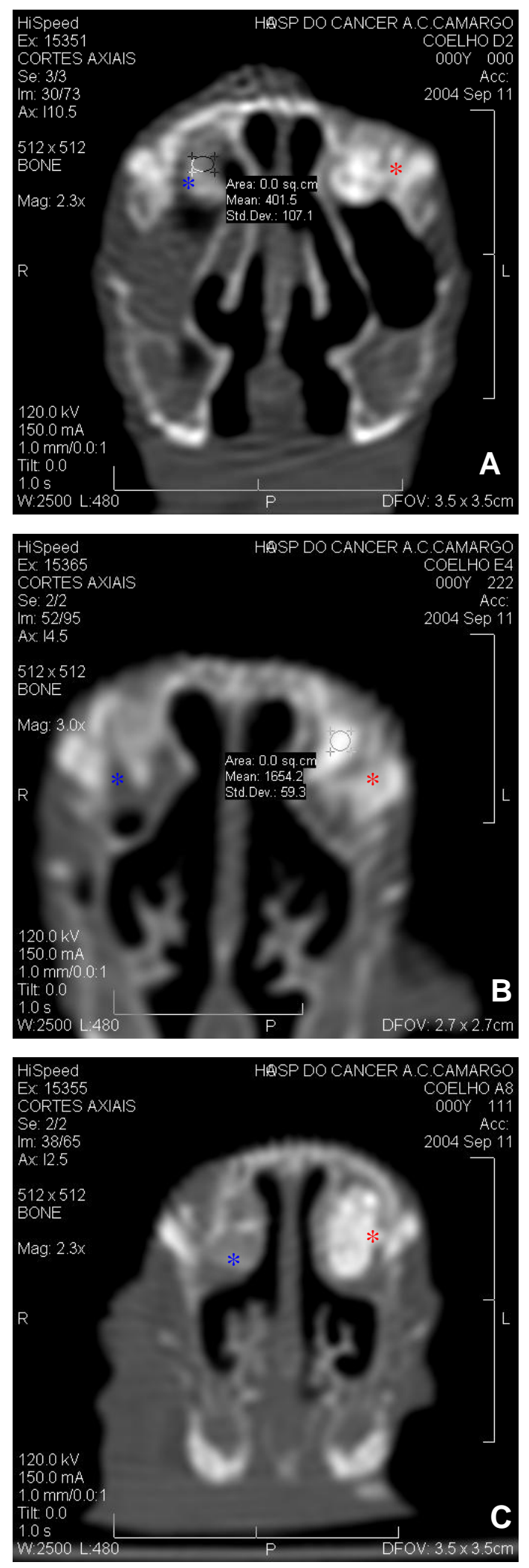

FIGURA 4. Tomografia computadorizada em animal do período de 2 (A), 4 (B) e 8 semanas (C). Seio maxilar preenchido pelo biomaterial $\left(^{*}\right)$ e seio maxilar preenchido com osso autógeno $\left(^{*}\right)$. 


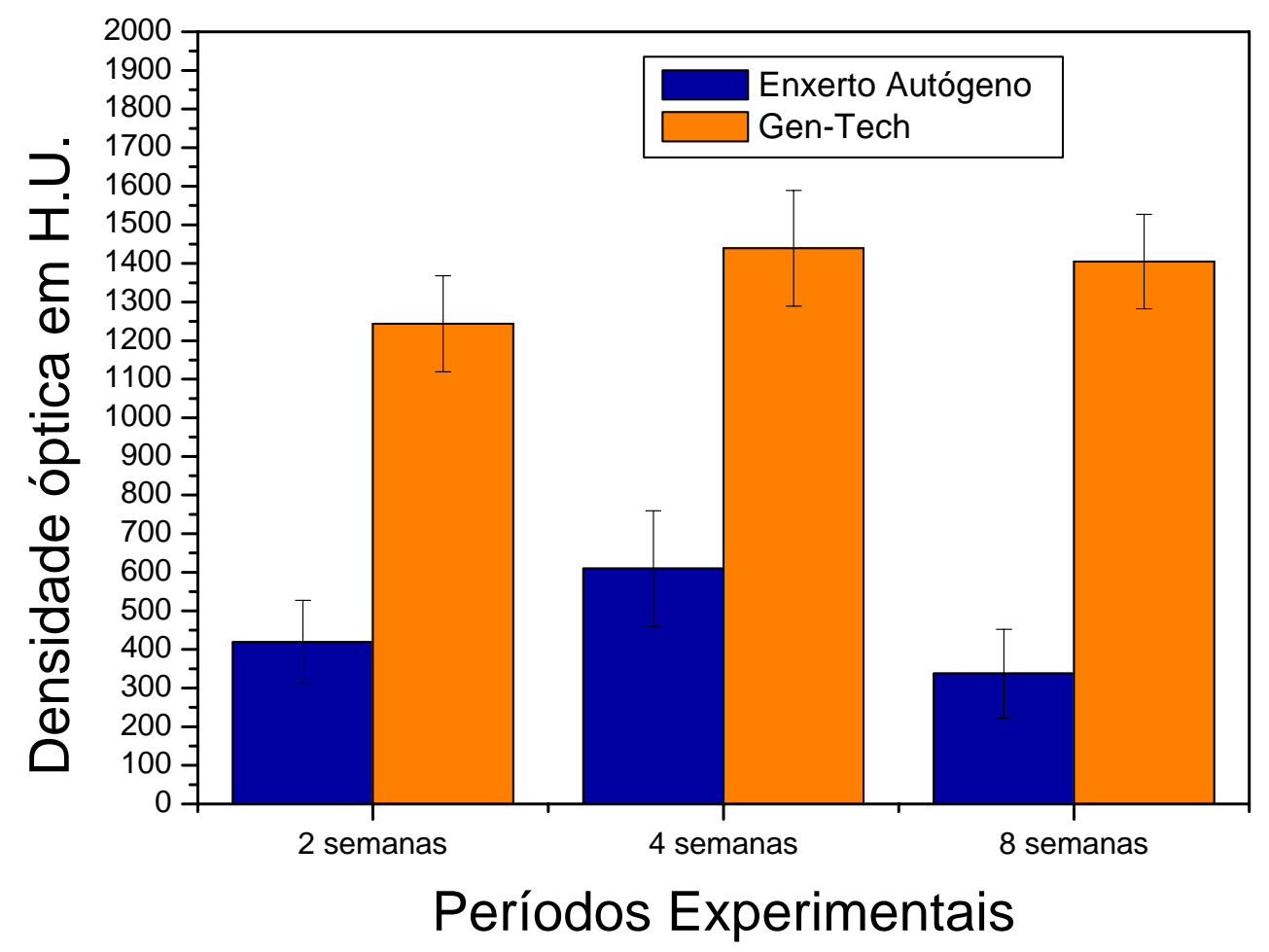

FIGURA 5. Densidade óssea obtida pela análise tomográfica dos dois grupos experimentais (Enxerto autógeno e Gen-Tech $\circledast$ ) nos períodos de 2, 4 e 8 semanas. 


\subsection{Análise histológica descritiva}

\section{Período de 2 semanas}

O início da neoformação óssea ocorreu a partir das bordas dos seios maxilares envolvendo as partículas de enxerto autógeno no grupo controle (FIGURA 6 A), e as partículas do componente inorgânico do biomaterial no grupo teste (FIGURA 6 D), com a aposição direta de tecido ósseo na superfície do enxerto autógeno (FIGURA 6 B e C) e do biomaterial (FIGURA 6 E e F). Observou-se infiltrado inflamatório localizado estritamente ao redor do componente orgânico do biomaterial no grupo teste (FIGURA 7). Entre e ao redor das partículas do enxerto ocorreu intensa formação de tecido conjuntivo e/ou granulação em ambos os grupos (FIGURA 6 B e E). No grupo controle, a neoformação óssea primária foi observada em todos os animais, enquanto no grupo teste a intensidade da neoformação variou muito dentro do grupo, não sendo detectada em 2 animais.

\section{Período de 4 semanas}

Neste período, o infiltrado inflamatório não estava presente em qualquer dos grupos avaliados. No grupo teste, não foram observados sinais do seu componente orgânico. A capacidade osteocondutora de ambos materiais foi claramente observada pela aposição óssea da borda para o centro do seio maxilar (FIGURA 8 A e D), diretamente em contato com o osso autógeno e matriz inorgânica do biomaterial (FIGURA 8 C e F). O tecido conjuntivo neoformado apresentou-se mais organizado nos dois grupos (FIGURA 8 B e E). A presença de tecido mielóide (FIGURA 8 B) e osteoclastos (FIGURA $8 \mathrm{C}$ ) foi observada exclusivamente no grupo controle.

\section{Período de 8 semanas}

Neste período, a presença de tecido ósseo neoformado e tecido mielóide foi muito evidente em ambos os grupos experimentais (FIGURA 9 A, C e D). Poucas partículas de osso autógeno foram observadas no controle em comparação com a ampla presença do componente inorgânico 
do biomaterial no grupo teste (FIGURA 9 B e E), exibindo aposição óssea em sua superfície e células do tecido conjuntivo em seus poros (FIGURA $9 \mathrm{E}$ e F). 


\section{Grupo Controle}
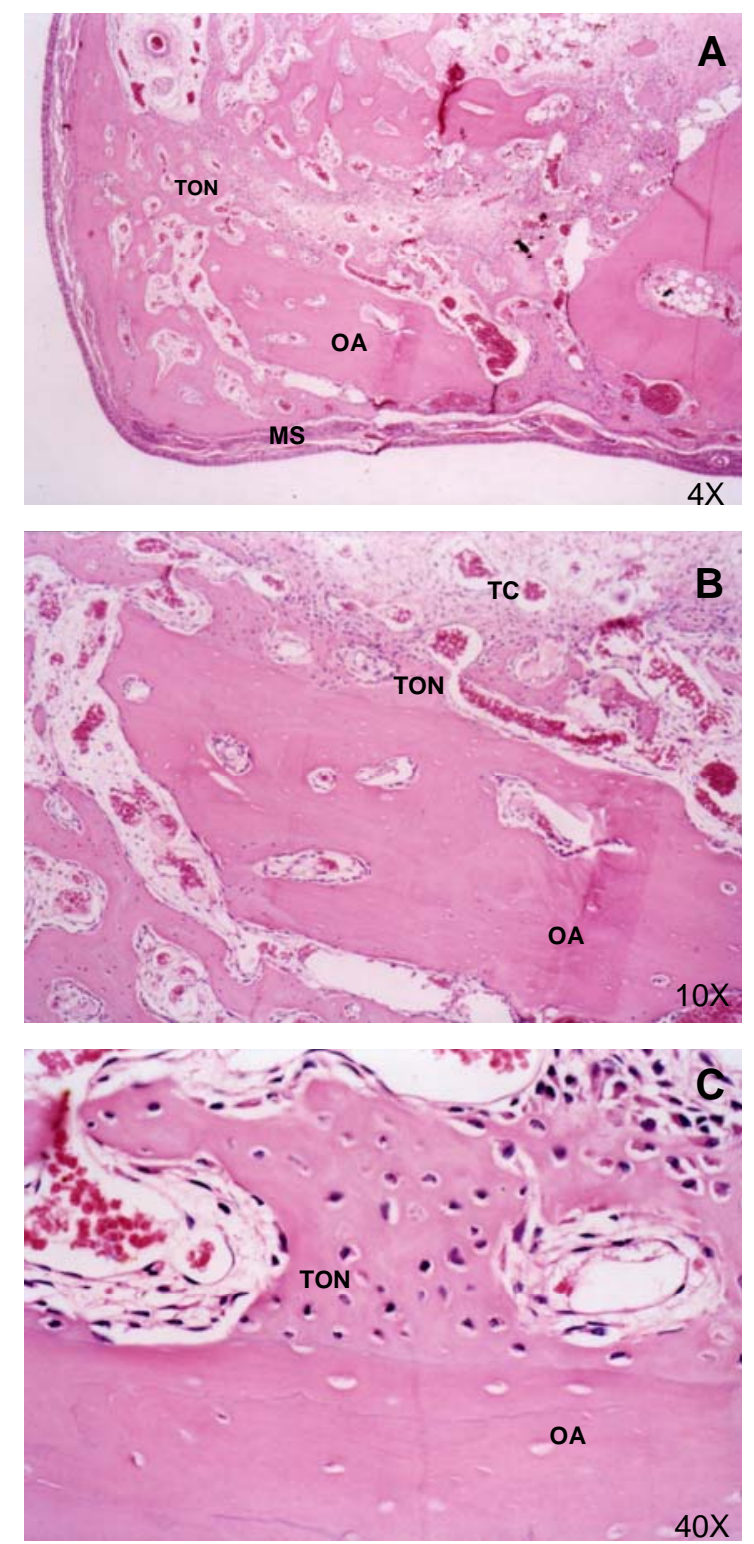

Grupo Teste
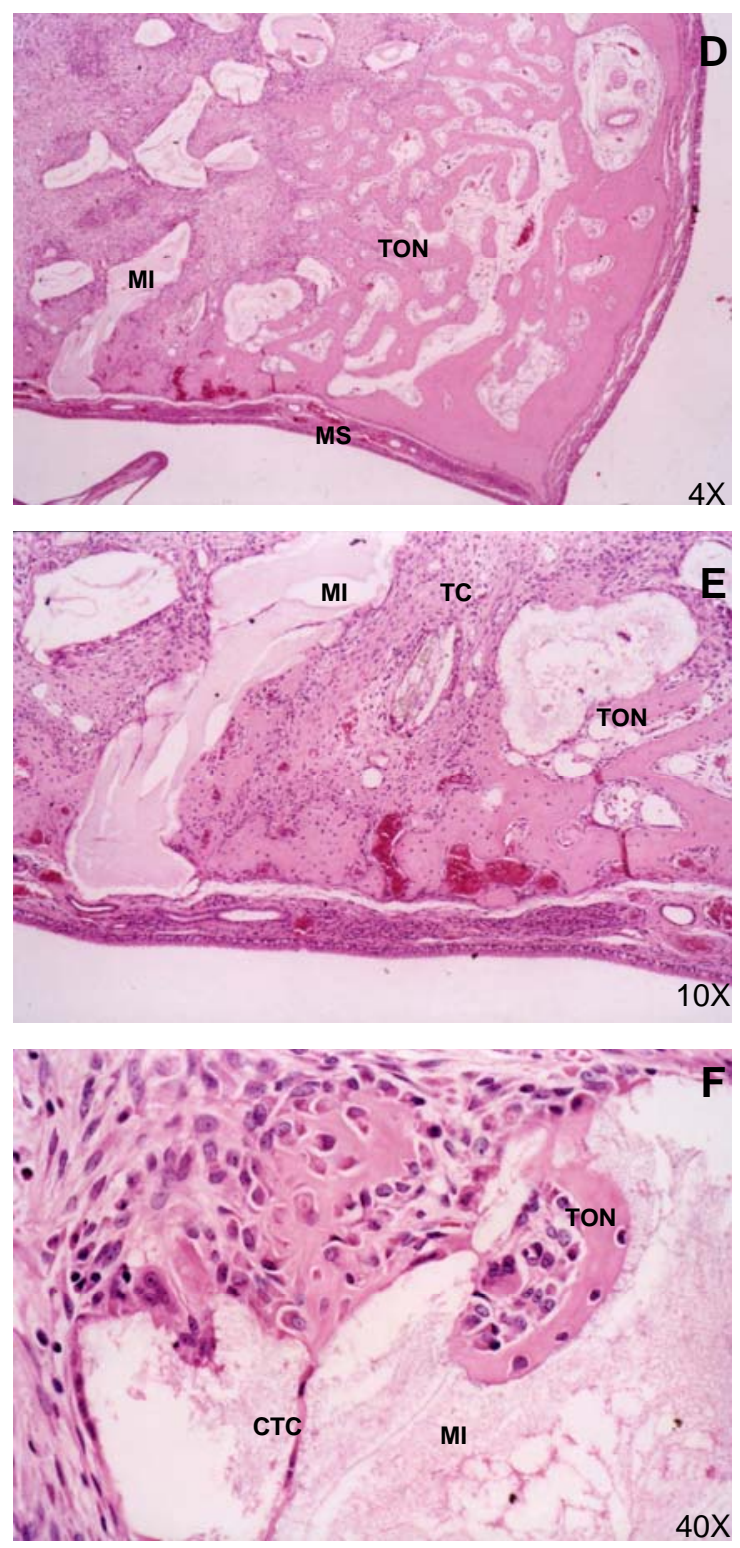

FIGURA 6. Período de 2 semanas. Grupo Controle (A,B e C) e Grupo Teste (D, E e F). Observa-se a neoformação óssea a partir da região adjacente à membrana sinusal (MS) seguindo pelas partículas de osso autógeno (OA) em A e B e pelas partículas de material inorgânico (MI) em D e E. Nota-se em $B$ e $E$ a presença de tecido conjuntivo (TC). Em C aposição de tecido ósseo neoformado (TON) em partícula de OA. Em F aposição de tecido ósseo neoformado em partícula inorgânica e células do tecido conjuntivo (CTC) nos poros do material. Coloração hematoxilina-eosina. 


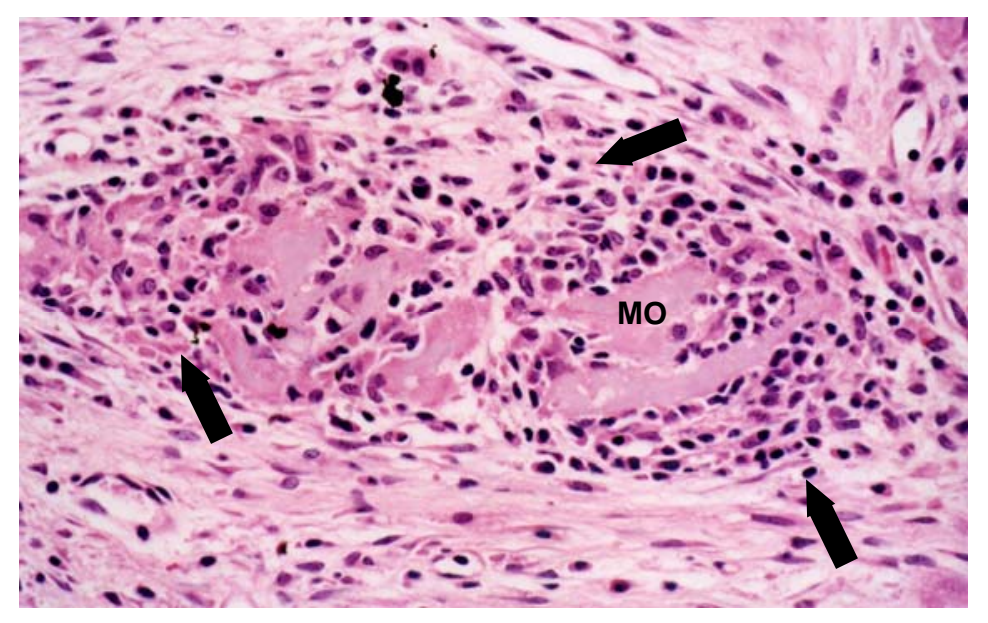

FIGURA 7. Grupo teste no período de 2 semanas. Infiltrado inflamatório (setas) ao redor do material orgânico (MO). Coloração hematoxilina-eosina. 


\section{Grupo controle}
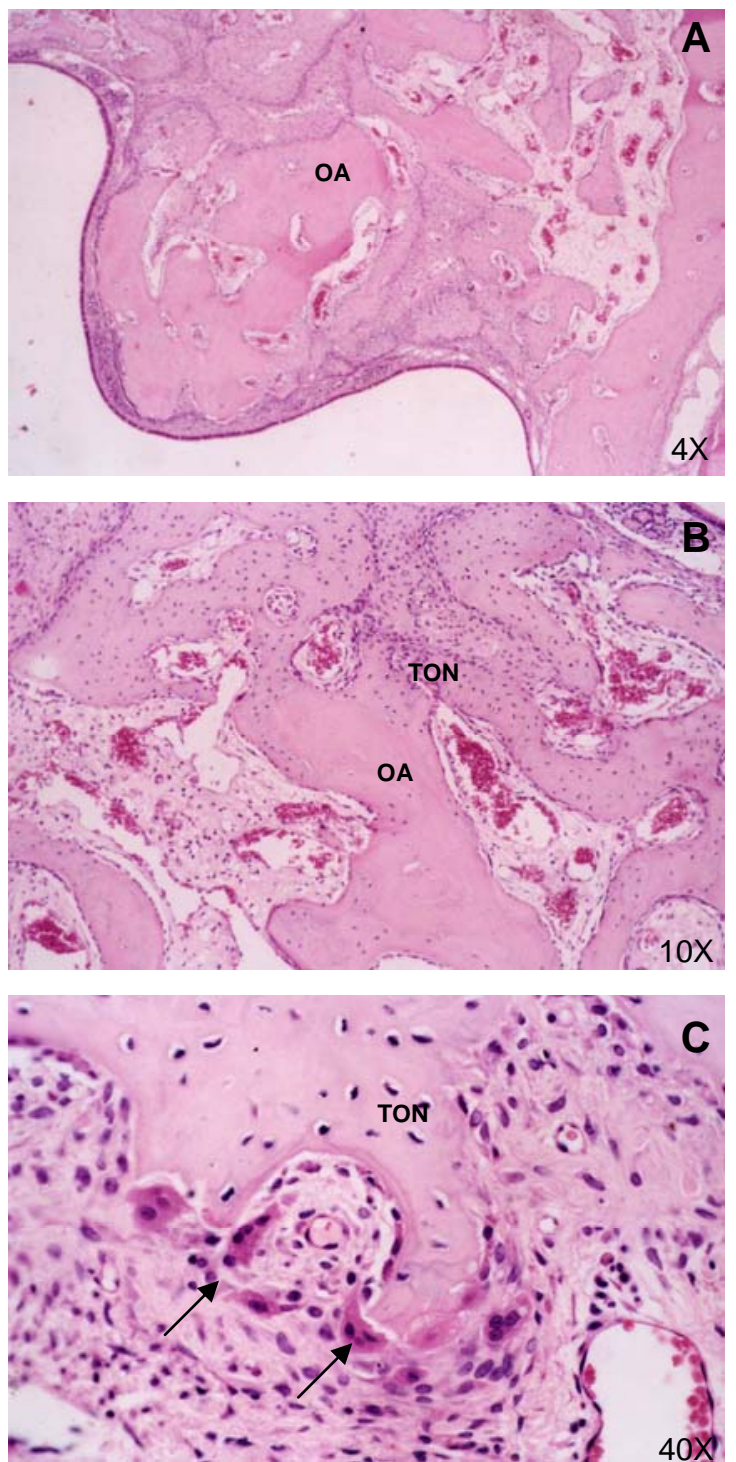

Grupo Teste
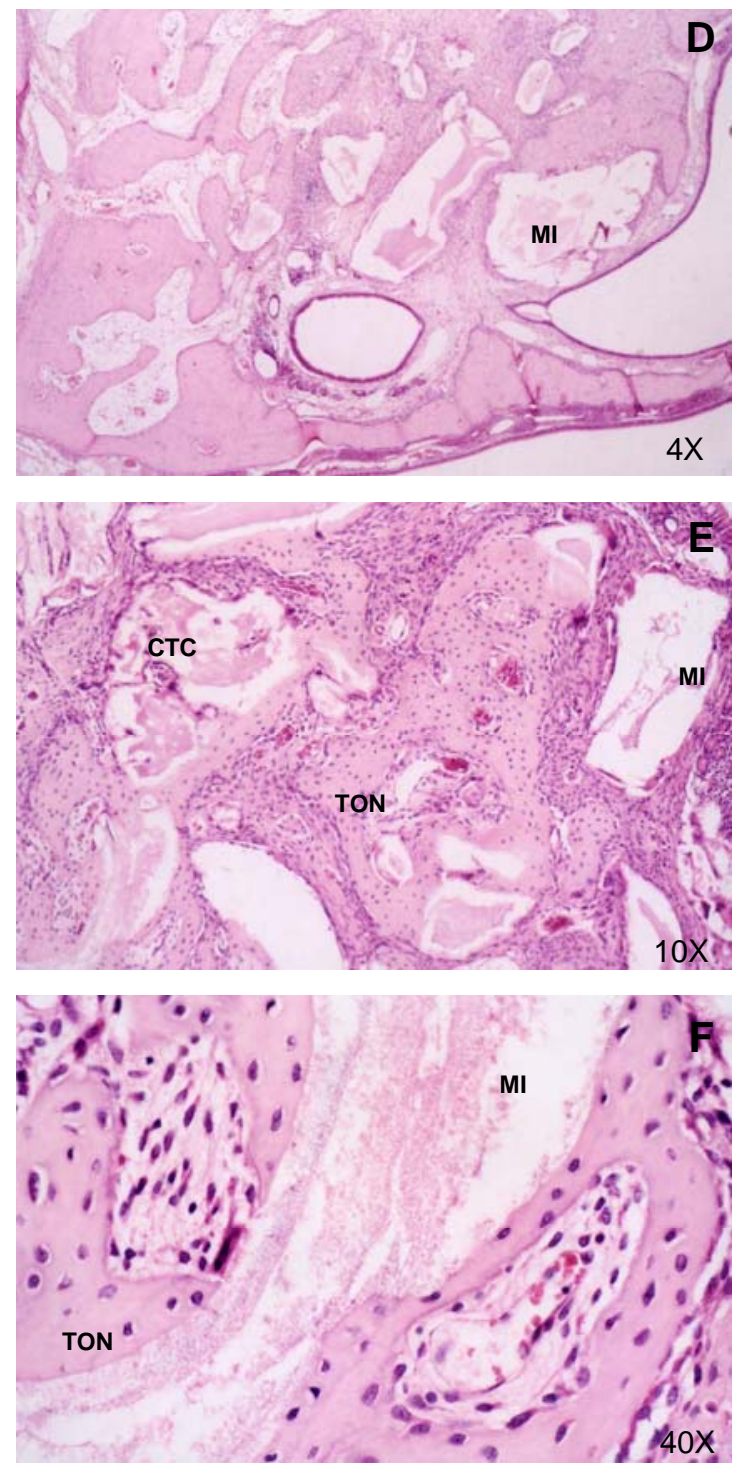

FIGURA 8. Período de 4 semanas. Em A e D, seio maxilar preenchido com osso autógeno e biomaterial, respectivamente. Em $B$, neoformação óssea (TON) ao redor de partícula de osso autógeno (OA). Em E, tecido ósseo neoformado ao redor de material inorgânico (MI) e células do tecido conjuntivo (CTC) nos poros do material. Em C, presença de osteoclastos (setas) na superfície de tecido ósseo neoformado. Em F, aposição de tecido ósseo neoformado (TON) em partícula de material inorgânico. Coloração hematoxilina-eosina. 
Grupo Controle
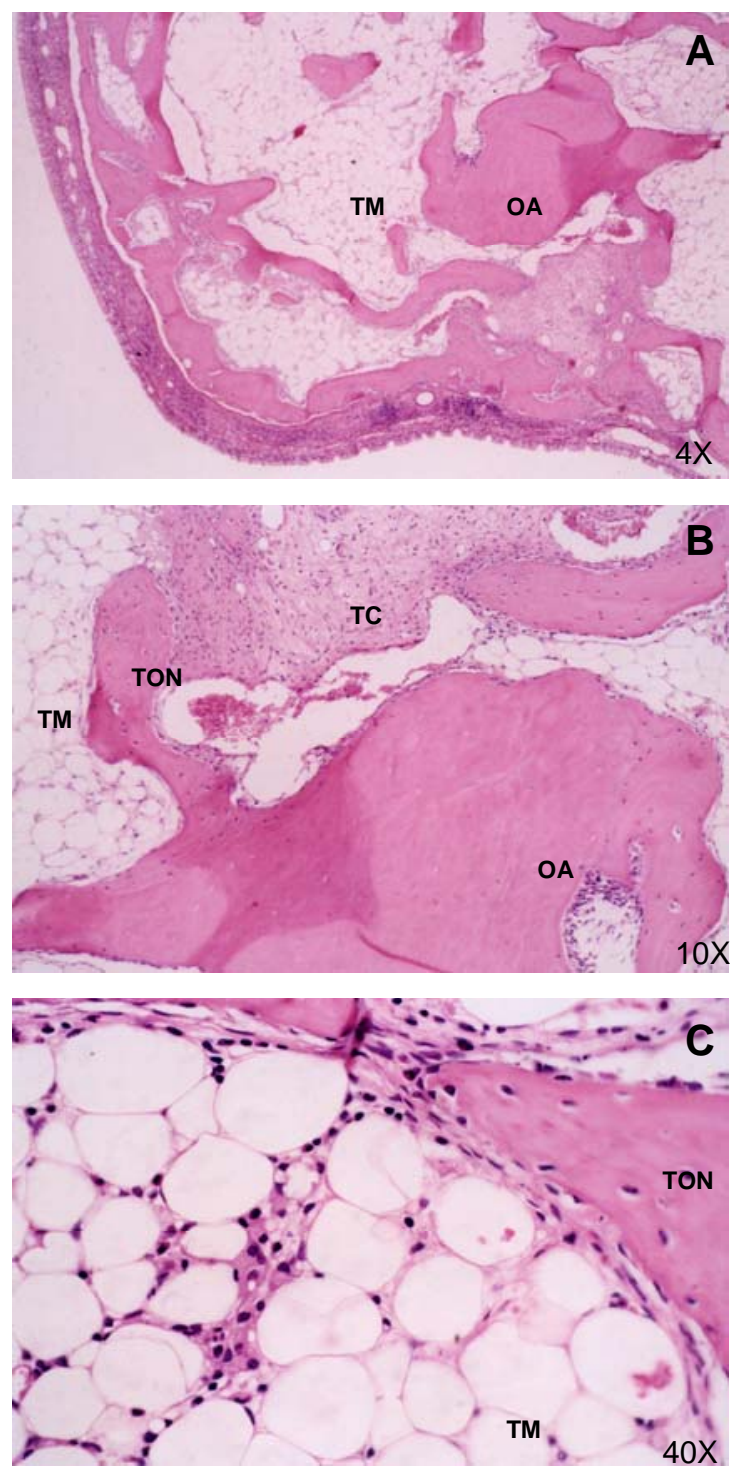

Grupo Teste
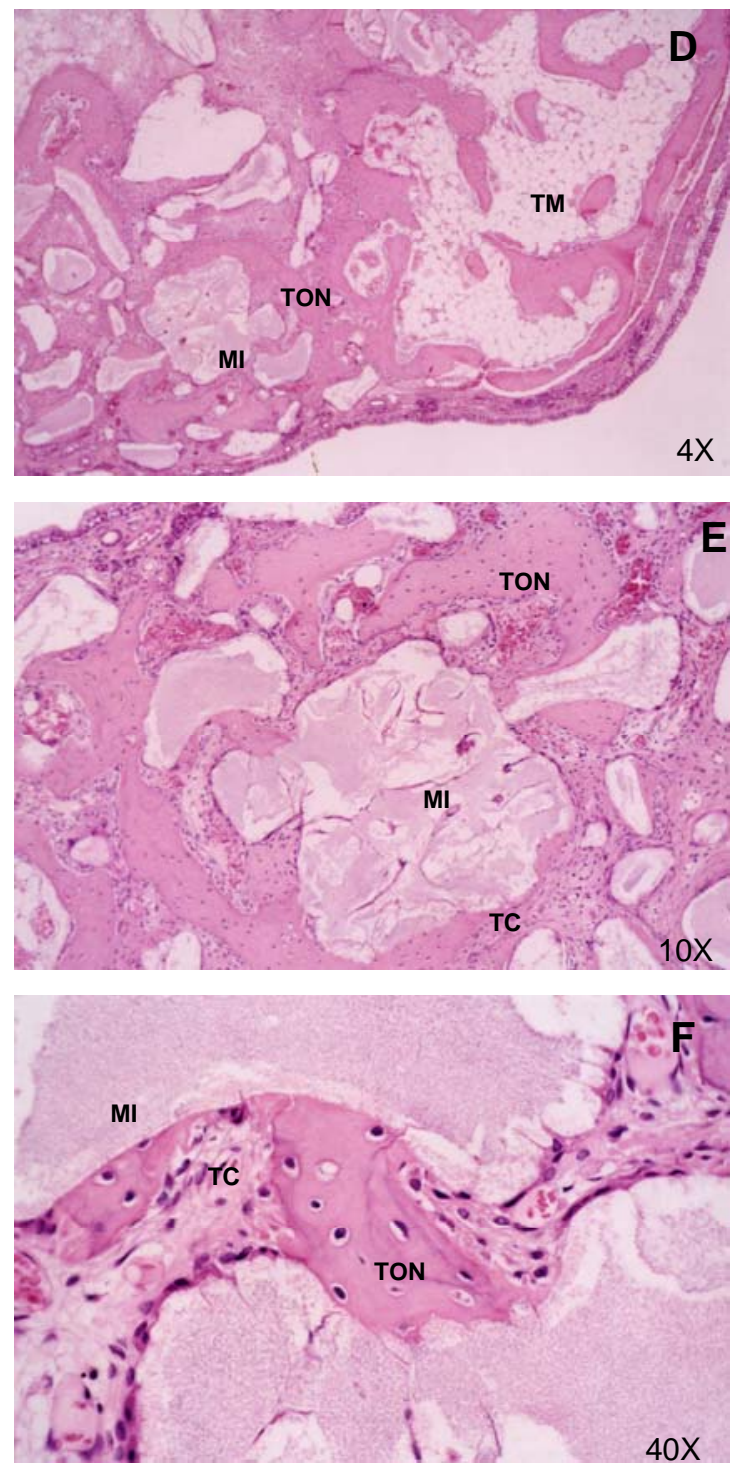

FIGURA 9. Período de 8 semanas. Em A observa-se a presença de tecido mielóide (TM) em grande parte da região. Em B, nota-se, ainda, partículas de osso autógeno (OA) não reabsorvidas e tecido conjuntivo (TC) mais organizado. Em C, presença de tecido ósseo neoformado e tecido mielóide. Em D, presença de tecido mielóide e tecido ósseo neoformado ao redor das partículas, claramente observado em E e F. Células do tecido conjuntivo mais organizado (F) são notadas no interior de poros do matriz inorgânica (E). Coloração hematoxilina-eosina. 


\subsection{Análise histomorfométrica}

Nesta análise foram verificadas as densidades de volume de tecido conjuntivo e/ou tecido de granulação, infiltrado inflamatório, material implantado (componente inorgânico e orgânico do biomaterial e enxerto autógeno), tecido ósseo neoformado e tecido mielóide. Os resultados obtidos encontram-se resumidos nas TABELAS 1 e 2.

No decorrer dos períodos experimentais houve diminuição da densidade de volume de tecido conjuntivo e/ou tecido de granulação no grupo controle, sendo detectado diferenças estatisticamente significativas entre 2 e 4 semanas $(P<0,05), 2$ e 8 semanas $(P<0,001)$ e 4 e 8 semanas $(P<0,001)$. No grupo teste a porcentagem de tecido conjuntivo e/ou tecido de granulação manteve-se estável nos períodos de 2 e 4 semanas $(P>0,05)$, tendo diminuído apenas após 4 semanas $(P<0,001)$. A comparação entre os grupos (controle $x$ teste) não mostrou diferenças estatisticamente significativas nos períodos de 2 e 4 semanas ( $P>0,05)$, já no período de 8 semanas a densidade de volume de tecido conjuntivo foi cerca de 2,5 vezes menor no grupo controle ( $P<0,001)$ (FIGURA 10).

Infiltrado inflamatório agudo foi observado apenas em 4 animais do grupo teste exclusivamente no período de 2 semanas, com um porcentual médio de 2,02\% ( $\pm 2,34$, min 0,0 - $\max 6,08)$.

Observou-se a diminuição na densidade de volume das partículas de enxerto autógeno com diferença estatisticamente significante apenas entre 4 e 8 semanas $(P<0,001)$, já no grupo teste não houve diminuição na quantidade de partículas inorgânicas do biomaterial entre os períodos experimentais. Traços da matriz orgânica foram observados apenas no período de 2 semanas na porcentagem de 0,79\% ( $\pm 0,71$, min 0,0 - max 1,6). A densidade de volume de material enxertado residual, comparando-se os grupos experimentais, mostrou-se menor $(P<0,01)$ no grupo controle em todos os períodos experimentais (FIGURA 11).

A percentagem de neoformação óssea manteve-se constante nos três períodos experimentais no grupo controle $(P>0,05)$, perfazendo cerca de $28,9 \%( \pm 6,7)$ do defeito na $8^{a}$ semana. No grupo teste, em relação ao 
período de 2 semanas, houve aumento significativo $(P<0,05)$ apenas no período de 8 semanas, que apresentou $24,2 \%( \pm 5,8)$. Entre os dois grupos experimentais não houve diferenças estatisticamente significativas na densidade de volume de neoformação óssea nos 3 períodos (FIGURA 12).

A densidade de volume de tecido mielóide foi cerca de 2 vezes maior no Grupo Controle, ocupando uma área de $64,1 \%( \pm 7,5)$, contra 32,3\% ( \pm $21,7)$ do Grupo Teste. Neste último, destaca-se que a variação entre os animais foi de cerca de 10 vezes, sendo a área mínima observada de 5,6\% e a máxima de $52 \%$. 
TABELA 1. Densidade de volume (\%). Grupo: Controle.

\begin{tabular}{|c|c|c|c|c|c|c|c|c|c|c|c|c|}
\hline \multirow{2}{*}{ Animal } & \multicolumn{3}{|c|}{ Tecido Conjuntivo } & \multicolumn{3}{|c|}{ Enxerto Autógeno } & \multicolumn{3}{|c|}{ Osso Neoformado } & \multicolumn{3}{|c|}{ Tecido Mielóide } \\
\hline & $2^{a}$ & 4 & 8 & 2 & 4 & 8 & 2 & 4 & 8 & 2 & 4 & 8 \\
\hline A & 64,43 & 47,19 & 5,25 & 16,80 & 9,32 & 2,39 & 18,46 & 18,42 & 27,84 & 0,31 & 25,05 & 64,52 \\
\hline B & 73,00 & 58,18 & 3,00 & 16,00 & 10,10 & 5,97 & 11,00 & 26,15 & 40,45 & 0,00 & 5,50 & 50,58 \\
\hline C & 69,03 & 42,71 & 3,87 & 5,43 & 14,42 & 2,50 & 25,48 & 34,54 & 30,13 & 0,00 & 8,32 & 63,50 \\
\hline D & 74,00 & $n d^{b}$ & 5,25 & 5,60 & nd & 4,40 & 20,4 & nd & 25,50 & 0,00 & nd & 64,85 \\
\hline E & 69,36 & 41,5 & 3,83 & 9,31 & 17,08 & 2,70 & 21,31 & 41,42 & 20,28 & 0,00 & 0,00 & 73,18 \\
\hline $\mathbf{F}$ & 74,45 & 63,63 & 0,32 & 10,34 & 17,18 & 3,00 & 15,21 & 19,18 & 28,98 & 0,00 & 0,00 & 67,70 \\
\hline MÉDIA & 70,71 & 50,64 & 3,59 & 10,58 & 13,62 & 3,49 & 18,64 & 27,94 & 28,86 & 0,05 & 7,77 & 64,06 \\
\hline DP & 3,85 & 9,79 & 1,83 & 4,92 & 3,74 & 1,42 & 5,04 & 9,94 & 6,66 & 0,13 & 10,30 & 7,47 \\
\hline
\end{tabular}

${ }^{\text {a }}$ Período experimental: 2, 4 e 8 semanas

${ }^{\mathrm{b}}$ nd: não determinado, animal excluído por ter desenvolvido sinusite. 
TABELA 2. Densidade de volume (\%). Grupo: Teste.

\begin{tabular}{|c|c|c|c|c|c|c|c|c|c|c|c|c|}
\hline \multirow{2}{*}{ Animal } & \multicolumn{3}{|c|}{ Tecido Conjuntivo } & \multicolumn{3}{|c|}{ Matriz Inorgânica } & \multicolumn{3}{|c|}{ Osso Neoformado } & \multicolumn{3}{|c|}{ Tecido Mielóide } \\
\hline & $2^{a}$ & 4 & 8 & 2 & 4 & 8 & 2 & 4 & 8 & 2 & 4 & 8 \\
\hline A & 66,65 & 50,93 & 14,37 & 17,46 & 29,08 & 11,22 & 14,48 & 19,9 & 23,48 & 0,00 & 0,00 & 50,91 \\
\hline B & 55,93 & 40,18 & 14,56 & 18,25 & 48,23 & 22,78 & 22,48 & 11,57 & 35,58 & 0,00 & 0,00 & 27,06 \\
\hline C & 57,73 & 40,97 & 45,62 & 33,38 & 25,71 & 26,52 & 1,08 & 33,31 & 21,67 & 0,00 & 0,00 & 5,60 \\
\hline D & 65,14 & 44,42 & 15,9 & 31,16 & 43,92 & 15,41 & 1,75 & 11,64 & 19,08 & 0,00 & 0,00 & 49,41 \\
\hline E & 65,03 & 67,28 & 29,93 & 20,36 & 21 & 38,06 & 10,85 & 11,71 & 23,50 & 0,00 & 0,00 & 8,50 \\
\hline $\mathbf{F}$ & 59,6 & 43,26 & 10,1 & 29,33 & 29,63 & 15,78 & 8,78 & 27,08 & 21,67 & 0,00 & 0,00 & 52,45 \\
\hline MÉDIA & 61,68 & 47,84 & 21,75 & 24,99 & 32,93 & 21,63 & 9,90 & 19,20 & 24,16 & 0,00 & 0,00 & 32,31 \\
\hline DP & 4,49 & 10,25 & 13,51 & 7,08 & 10,72 & 9,76 & 8,07 & 9,307 & 5,82 & 0,00 & 0,00 & 21,69 \\
\hline
\end{tabular}

${ }^{\text {a }}$ Período experimental: 2, 4 e 8 semanas 


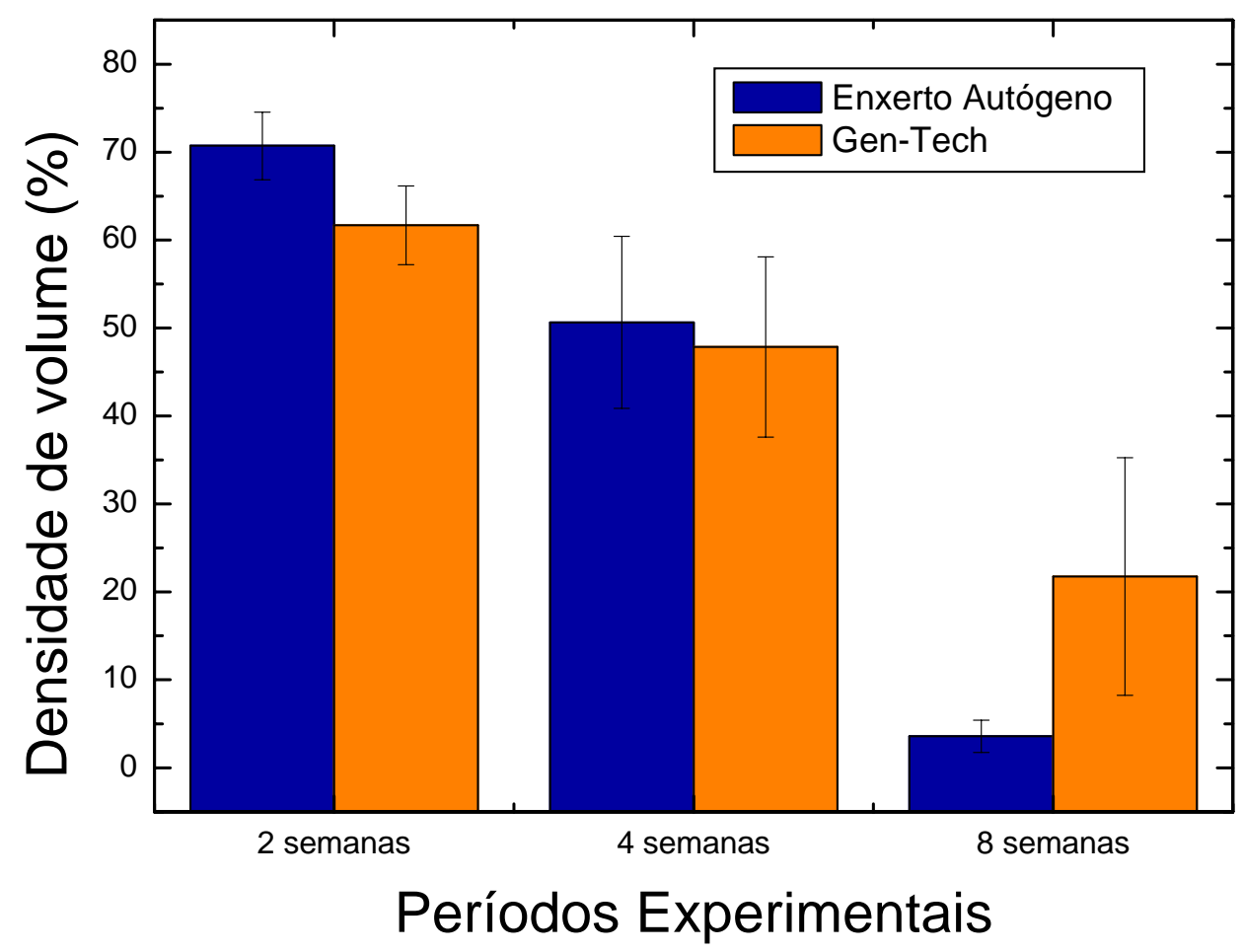

FIGURA 10. Gráfico representando a densidade de volume de tecido conjuntivo e/ou tecido de granulação, em porcentagem, dos grupos teste e controle em função dos períodos experimentais. 


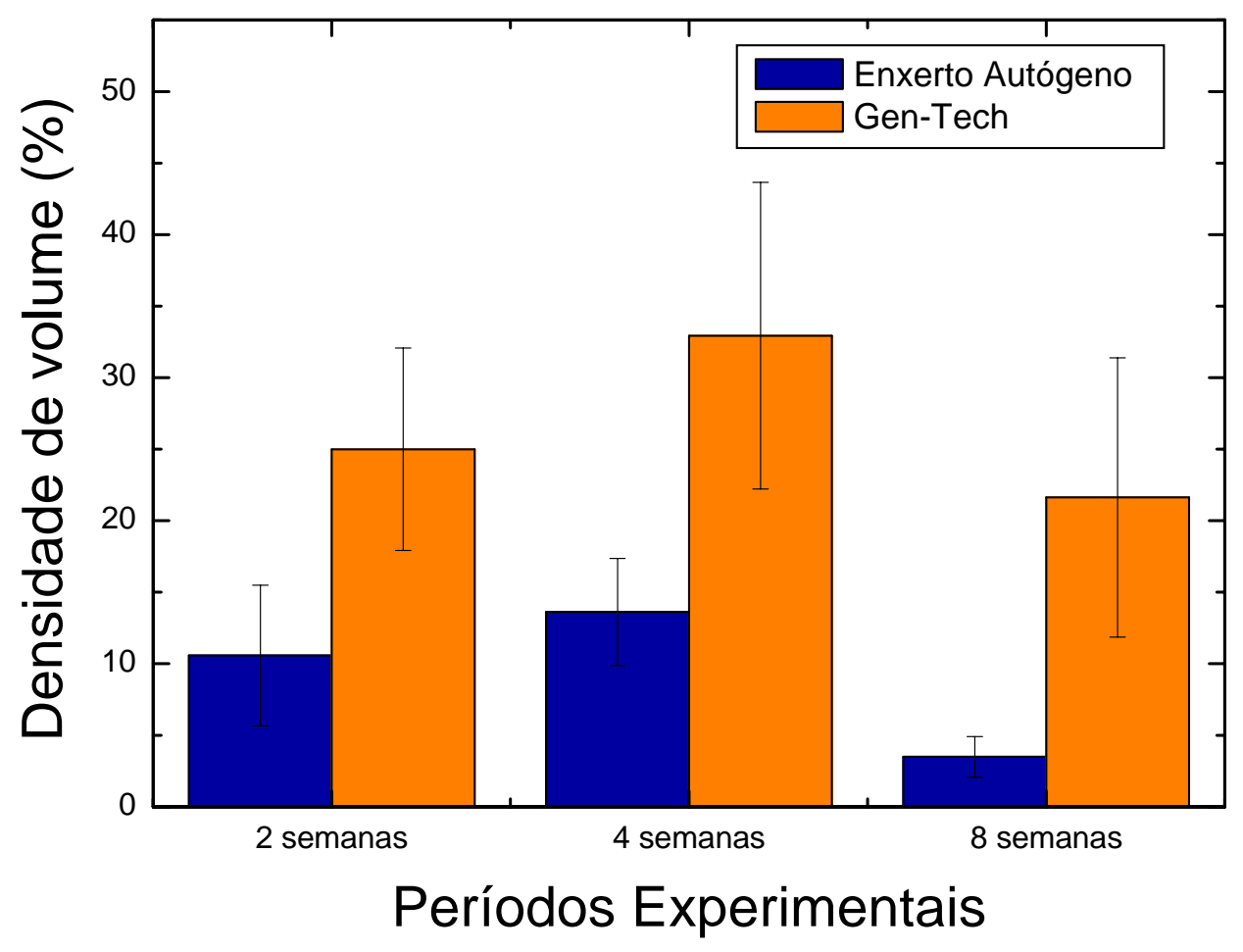

FIGURA 11. Gráfico representando a densidade de volume de enxerto de osso autógeno, no grupo controle, e biomaterial Gen-Tech ${ }^{\circledR}$, no grupo teste, em porcentagem, em função dos períodos experimentais. 


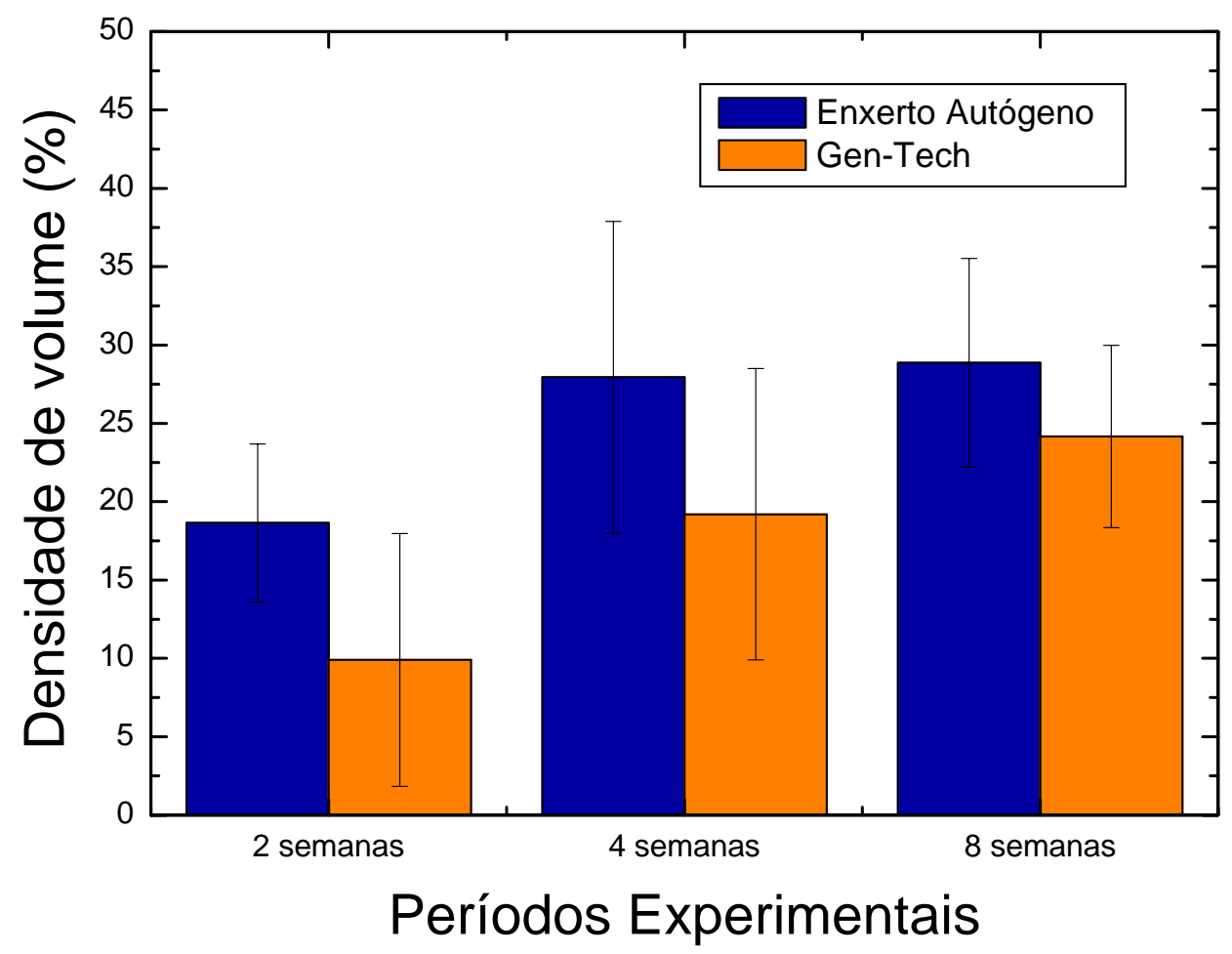

FIGURA 12. Gráfico representando a densidade de volume de tecido ósseo neoformado, em porcentagem, dos grupos teste e controle em função dos períodos experimentais. 


\section{DISCUSSÃO}

O levantamento de seio maxilar é um procedimento comumente utilizado para aumentar a altura óssea da maxila posterior possibilitando a colocação de implantes endoósseos. Para esse tipo de procedimento cirúrgico, avaliando apenas as propriedades biológicas como a capacidade de osteoindução, osteocondução e osteogênese, o osso autógeno é considerado o material "gold standard" para enxerto (TONG et al $\left.{ }^{67}, 1998\right)$. No entanto, desvantagens como morbidade da região doadora e maior custo para o paciente estimulam a pesquisa e desenvolvimento de materiais substitutos que possam ser alternativas seguras para o enxerto autógeno.

O biomaterial avaliado nesse estudo é um composto contendo matriz orgânica cortical e inorgânica medular, "pool" de proteínas ósseas morfogenéticas e colágeno, todos derivados de tecido ósseo bovino. $\mathrm{O}$ objetivo dessa formulação é associar a capacidade osteocondutora da matriz óssea inorgânica com o potencial osteoindutor da matriz óssea orgânica e das BMPs visando otimizar o reparo ósseo. A despeito dos componentes individuais deste composto já terem sido testados isoladamente e do material estar disponível no mercado nacional e internacional, seu efeito sinergístico ainda não foi avaliado em cirurgias buço-maxilofaciais. Assimn, nosso objetivo foi avaliar o Gen-Tech ${ }^{\circledR}$ como potencial material substituto ósseo ao osso autógeno (utilizado no grupo controle) em cirurgias de levantamento de seio maxilar.

O coelho foi utilizado como modelo experimental por ser um animal de porte relativamente pequeno e apresentar vantagens como baixo custo possibilitando, um número da amostra suficiente para análise estatística, além da facilidade no procedimento de anestesia comparando-se com animais de maior porte como macacos e cabras (WATANABE et $\mathrm{al}^{79}, 1999$; ASAl et $\mathrm{al}^{4}$, 2002).

Salientamos que no projeto piloto deste trabalho seguimos o protocolo proposto por WATANABE et al $^{79}$ (1999) e relatado por outros autores (WADA et $\mathrm{al}^{77}, 2001$; UEDA et $\mathrm{al}^{68}, 2001$ ), ou seja, utilizamos os seios 
maxilares inferiores do animal como leito receptor para o enxerto ósseo. No entanto, verificamos que o acesso cirúrgico realizado na lateral da face, próximo à artéria facial, resultava em hemorragias freqüentes e, em adição, que o pequeno volume da cavidade dificultava a colocação dos materiais de enxerto. Essas dificuldades nos impuseram a necessidade de seguir outro protocolo fundamentado em outras publicações científicas (ASAl et $\mathrm{al}^{4}$, 2002; XU et $\mathrm{al}^{82}$, 2003), utilizando os seios maxilares superiores do animal, com acesso por apenas uma incisão paralela à sutura naso-incisal. Nesse caso, as cirurgias foram realizadas em todos os animais sem a ocorrência de complicações pós-operatórias. Deste modo, em nossas condições de trabalho concluímos ser esse um modelo experimental adequado para o procedimento de levantamento de seio maxilar.

Nossos resultados histomorfométricos demonstraram que no grupo controle (enxerto autógeno) a densidade de volume de tecido ósseo neoformado manteve-se constante no decorrer dos períodos experimentais, confirmando os resultados de UEDA et $\mathrm{al}^{68}$ (2001). A despeito desses autores terem utilizado apenas a porção medular do tecido ósseo removido da crista ilíaca, utilizamos no presente trabalho as porções cortical e medular do osso autógeno. WATANABE et $a^{79}$ (1999), utilizando-se bloco de enxerto córtico-medular removido da crista ilíaca, não demonstrou aumento significativo entre o período de 2 a 4 semanas após a cirurgia, mas notou diminuição no período de 8 semanas. Por outro lado, WADA et al $^{77}$ (2001) relataram aumento significativo na densidade de volume ósseo neoformado após 4 semanas do enxerto e que se manteve constante até 8 semanas quando apenas a porção medular do tecido da crista ilíaca foi utilizada.

Quanto aos seios maxilares preenchidos pelo biomaterial (grupo teste), verificamos que o aumento na densidade de volume ósseo foi significativo apenas após 8 semanas, diferentemente do reportado por XU et $\mathrm{al}^{83}$ (2004) que, utilizando matriz óssea inorgânica, observaram aumento significativo na densidade de volume ósseo já no período de 4 semanas, estabilizando entre 8 a 10 semanas após a implantação do material.

A tomografia computadorizada (TC) permitiu avaliar a densidade 
óssea entre os dois materiais de enxerto utilizados, assim como entre os períodos experimentais. Salientamos que essa análise possui alta resolução, sendo que diferenças na densidade menores de $1 \%$ podem ser observadas, como comparação as radiografias convencionais requerem $10 \%$ de diferença (FREDERIKSEN ${ }^{43}$, 2003). O grupo teste apresentou uma densidade maior do que $1000 \mathrm{HU}$, que é equivalente a de um tecido ósseo denso e representa o valor máximo da escala. Essa alta densidade deve-se à presença da matriz inorgânica do composto que, durante o processo de produção é tratada a cerca de $950^{\circ} \mathrm{C}$, promovendo aumento de densidade e, portanto, de radiopacidade. Por outro lado, no grupo controle, houve aumento da densidade óssea no período de 4 semanas e diminuição no período de 8 semanas. Mesmo não havendo diferenças estatisticamente significativas na densidade de volume de osso neoformado nesses períodos, esse fato pode estar relacionado ao aumento no grau de mineralização do osso primário formado até a $4^{\mathrm{a}}$ semana e à remodelação óssea com considerável aumento de tecido mielóide e redução na densidade de volume do enxerto até a 8 ${ }^{\mathrm{a}}$ semana. Já no grupo teste, não achamos correlação dos dados obtidos pela TC com os dados histomorfométricos, talvez pela alta densidade óssea que ultrapassou o valor máximo da escala H.U. Nesse sentido, convém salientar que a TC foi utilizada na avaliação de densidade após o uso de esponja de colágeno com rhBMP-2 em cabras, sendo constatado aumento na densidade ótica após 6 semanas, porém não houve correlação dos dados com os resultados da análise histológica (KIRKERHEAD et $\mathrm{al}^{31}$, 1997). Em humanos, também não foi encontrada correlação entre a densidade óssea verificada pela TC com a análise histomorfométrica (SCHULTZE-MOSGAU et $\mathrm{al}^{57}$, 2001). Deste modo, pretendemos, futuramente, correlacionar os dados obtidos nesse estudo a fim de verificar se a utilização da TC efetivamente provê informações seguras sobre o que está ocorrendo em termos histológicos na região do reparo.

Entretanto, o resultado mais relevante do presente estudo é a constatação de que não houve diferenças nas porcentagens de tecido ósseo neoformado entre os dois grupos experimentais em todos os períodos. Deste 
modo, nosso estudo corrobora o relato de JOHN e WENZ ${ }^{29}$ (2004), em humanos, que não mostrou diferenças estatisticamente significativas entre a utilização isolada de osso inorgânico xenogênico, osso inorgânico associado ao enxerto autógeno obtido da região mentoniana e apenas o enxerto autógeno. No entanto é importante salientar que há poucos estudos clínicos controlados comparativos utilizando-se biomateriais e osso autógeno neste procedimento cirúrgico em humanos.

A análise histológica confirmou a capacidade osteocondutora da porção inorgânica medular deste composto, verificada pela aposição de tecido ósseo neoformado diretamente em sua superfície, confirmando relatos anteriores da literatura para biomateriais inorgânicos de origem bovina de outras marcas comerciais (HURZELER et $\mathrm{al}^{26}, 1997$, INDOVINA e BLOCK $^{27}$, 2002; VALENTINI e ABENSUR ${ }^{72}$, 2003).

É desejável que biomateriais para enxerto ósseo sejam reabsorvidos e substituídos por tecido ósseo neoformado ao longo do tempo, regenerando as características biológicas originais do tecido. Entretanto, no presente estudo, a densidade de volume das partículas de matriz inorgânica desproteinizada não apresentaram sinais de degradação após 8 semanas, como reportado por XU et al $\left.\right|^{82,83}$ (2003 e 2004), ou mesmo após 64 semanas (XU et $\left.\mathrm{al}^{84}, 2005\right)$.

Corroborando essas observações, também em humanos, não foi demonstrada a diminuição na densidade de volume de hidroxiapatita de origem bovina até o período de 3 anos após procedimento de levantamento de seio maxilar (HALLMAN, et $\mathrm{al}^{21}$, 2002) e, após 4 anos, notou-se, ainda a mesma porcentagem de material inorgânico, porém já com a presença de osteoclastos ao seu redor (PIATTELLI et $\mathrm{al}^{49}$, 1999). Esta característica pode ser positiva se considerarmos que a baixa taxa de reabsorção pode prevenir a reabsorção óssea precoce à inserção de implantes dentários, mantendo o volume da área enxertada, o que não ocorre quando da utilização de enxerto autógeno, cuja taxa de reabsorção pode atingir 50\% do volume inicial enxertado após os primeiros 6 meses da cirurgia, resultando em posterior dificuldade na colocação de implantes (JOHANSSON et $\mathrm{al}^{28}$, 
2001), principalmente na região posterior da maxila que sofre o processo de pneumatização (XU et al ${ }^{83}$, 2004).

$\mathrm{Na}$ Implantodontia, a lenta reabsorção do biomaterial traz outra questão importante que trata do percentual de biomaterial em contato com o implante. HALLMAN et $\mathrm{al}^{21}$ (2002) não verificou diferença estatisticamente significativa entre implantes colocados após um período de 6 a 9 meses em levantamento de seios maxilares humanos com 100\% de enxerto autógeno, mistura de $80 \%$ de HA de origem bovina e $20 \%$ de enxerto autógeno ou $100 \%$ de HA de origem bovina. O mesmo foi observado por BERGLUNDH e LINDHE$^{5}$ (1997) em análise histomorfométrica em preenchimento de alvéolos dentários em cães. FROUM et $\mathrm{al}^{17}$ (1998), em um estudo clínico controlado, observaram que a matriz óssea bovina inorgânica mostrou-se efetiva quando utilizada em levantamento de seio maxilar, sendo relatado aumento de tecido ósseo neoformado com o tempo além de uma taxa de sucesso de mais de 98\% na colocação de implantes dentários.

Nossos resultados indicaram retardo no processo de reparo ósseo no grupo teste nas primeiras duas semanas pós-enxerto, coincidindo com o infiltrado inflamatório observado nesse período, exclusivamente ao redor das partículas de cortical orgânica do composto, que já haviam desaparecido totalmente nos períodos subseqüentes. Estes dados sugerem que a resposta inflamatória, levando à rápida reabsorção do material, eliminou a potencial capacidade osteoindutora das BMPs presentes na matriz óssea desmineralizada. A maturação óssea mostrou-se maior no grupo controle, reforçando a sugestão de que a resposta inflamatória inicial no grupo teste atrasou o processo de reparo ósseo.

HASS et $\mathrm{al}^{23}$ (2002) utilizando osso desmineralizado, homógeno ou heterógeno, juntamente com a colocação de implantes dentários em ovelhas observaram resultados similares e a não ocorrência de benefícios quando comparados à colocação de implantes em áreas não enxertadas, porém a presença de infiltrado inflamatório não foi relatada, pois o menor período experimental foi de 12 semanas. BÖECK-NETO et $\mathrm{al}^{6}$ (2002) relataram neoformação óssea semelhante quando compararam enxerto ósseo 
autógeno combinado com HA de origem bovina, que possui apenas propriedade osteocondutora, com DFDBA, sendo que o grupo que utilizou HA apresentou maior organização do tecido medular. Em vista dos resultados desses estudos utilizando matrizes orgânicas e BMPs, particularmente xenogênicas, salientamos que é importante avaliar a intensidade da inflamação inicial e da resposta imunogênica, pois esta poderia resultar em destruição das proteínas no processo e, assim, eliminar o potencial osteoindutor.

HANISCH et al ${ }^{22}$ (1999), utilizando-se da combinação de DFDBA com HA bovina, relataram um aumento de $21 \%$ no volume ósseo em seios maxilares, no entanto como no seu estudo não foi utilizado um grupo controle, não foi possível verificar se o resultado obtido foi devido especificamente ao material. Mesmo relatando $100 \%$ de sucesso no preenchimento de 30 seios maxilares com DFDB seguido da instalação de 69 implantes, VAN DEN BERGH et $\mathrm{al}^{75}$ (2000) enfatizaram para a necessidade de um estudo clínico comparativo entre DFDB, osso autógeno e BMPs em levantamento de seio maxilar para melhores conclusões.

O potencial osteoindutor do "pool" de BMPs derivado de osso bovino e carreada por HA sintética reabsorvível também não pôde ser confirmado no atual estudo, pois não havia um grupo tratado com o composto sem esse componente. ALLEGRINI et $\mathrm{al}^{2}$ (2004) demonstraram, no mesmo modelo experimental, um aumento de $30 \%$ de neoformação óssea quando a um biomaterial composto era adicionado pool de BMPs carreado por HA reabsorvível sintética. Entretanto esse estudo não utilizou análise estatística para valorizar os resultados obtidos. Resposta similar foi observada quando em um dos seios maxilares do coelho foi colocado rhBMP-2 carreada por esponja de colágeno e, em outro, osso autógeno removido da crista ilíaca, sendo estatisticamente significativa a maior formação óssea no grupo com rhBMP-2 (WADA et al ${ }^{77}, 2001$ ). NEVINS et al ${ }^{43}$ (1996) também observaram um aumento de tecido ósseo significativamente maior quando utilizaram rhBMP-2 carreada em esponja de colágeno comparativamente à utilização apenas de esponja de colágeno, em cabras. Em humanos, BOYNE et al ${ }^{8}$ 
(1997) utilizando rhBMP-2 e esponja de colágeno em levantamento de seio maxilar em humanos, obtiveram aumento no volume ósseo possibilitando a colocação de implantes, concluindo que é uma possível alternativa ao enxerto de osso autógeno. No entanto, VAN DEN BERGH et al ${ }^{79}$ (2000) verificaram grande diferença na resposta entre os pacientes que receberam rhBMP-7 carreada por esponja de colágeno. No entanto esses estudos em humanos apresentavam uma pequena amostra não tendo grande relevância científica.

Em conjunto todos esses dados, em animais e humanos, indicam que não há ainda resultados conclusivos acerca da capacidade osteoindutora de BMPs recombinantes ou xenogênicas quando utilizadas em defeitos ósseos. Isto implica em mais estudos sobre o assunto verificando, inclusive, sobre o envolvimento de resposta imune ou inflamatória neutralizando a capacidade osteoindutora. Em todos os estudos similares a esse o uso de controle com osso autógeno é fundamental para avaliar o potencial do biomaterial como material osseosubstituto. 


\section{CONCLUSÃO}

A neoformação óssea induzida pelo biomaterial Gen-Tech® foi similar à induzida pelo enxerto de osso autógeno, no entanto o tecido ósseo neoformado apresentou-se mais maduro nos seios maxilares preenchidos pelo osso autógeno. 
ANEXO 


\section{REFERÊNCIAS BIBLIOGRÁFICAS}

1. ALLEGRINI JR., S., YOSHIMOTO, M. SALLES, M.B., KÖNIG JR., B. The effects of bovine BMP associated to HA in maxillary sinus lifting in rabbits. Ann Anat, v.185, n.4, p.343-9, July 2003.

2. ALLEGRINI JR., S., YOSHIMOTO, M., SALLES, M.B., KÖNIG JR., B. Bone regeneration in rabbit sinus lifting associated with bovine BMP. J Biomed Mater Res B Appl Biomater, v.68B, n.2, p.127131, Feb. 2004.

3. ARTZI, Z., NEMCOVSKY, C.E., TAL, H., DAYAN, D. Histomorphological morphometric evaluation of 2 different hydroxyapatite-bone derivatives in sinus augmentation procedures: a comparative study in humans. J Periodontol, v.72, n.7, p.911920, 2001.

4. ASAI, S., SHIMIZU, Y., OOYA, K. Maxillary sinus augmentation in rabbits: effect of occluded nasal ostium on new bone formation. Clin Oral Implant Res, v.13, n.4, p.420-7, Aug. 2002.

5. BERGLUNDH, T., LINDHE, J. Healing around implants placed in bone defects treated with Bio-Oss $®$ : an experimental study in the dog. Clin Oral Implant Res, v.8, n.2, p.117-124, Apr. 1997.

6. BÖECK-NETO, R.J., GABRIELLI, M., LIA, R., MARCANTONIO, E., SHIBLI, J.A., MARCANTONIO, E.JR. Histomorphometrical análisis of bone formed alter maxillary sinus floor augmentation by grafting with a combination of autogenous bone and demineralized freezedried bone allograft or hydroxyapatite. J Periodontol, v.73, n.3, p.266-70, Mar. 2002.

7. BOYNE, P. J., JAMES, R. A. Grafting of the maxillary sinus floor with autogenous morrow and bone. J Oral Surg, v.38, n.8, p.613-616, Aug. 1980.

\footnotetext{
* Normas recomendadas para uso no âmbito da Universidade de São Paulo, com base no documento "Referências Bibliográficas: exemplos", emanados do Conselho Supervisor do Sistema Integrado de Bibliotecas da USP, em reunião de 20 de setembro de 1990.
} 
8. BOYNE, P.J., MARX, R.E., NEVINS, M., TRIPLETT, G., LAZARO, E., LILLY, L.C., ALDER, M., NUMMIKOSKI, P. A feasibility study evaluating rhBMP-2/absorbable collagen sponge for maxillary sinus floor augmentation. Int J Periodontics Restorative Dent, v.17, n.1, p.11-25, Feb. 1997.

9. BURG, J.L.; PORTER, S.; KELLAM, J.F. Biomaterial developments for bone tissue engineering. Biomaterials, v. 21, p. 2347-2359, 2000.

10. CANCEDDA, R.; DOZIN, B.; GIANNONI, P.; QUARTZO, R. Tissue engineering and cell therapy of cartilage and bone. Matrix Biology, v.22, p.81-91, 2003.

11. CHAVANAZ, M. Maxillary sinus: anatomy, physiology, surgery, and bone grafting related to implantology-eleven years of surgical experience (1979-1990). J Oral Implantol, v.16, n.3, p.199-209, 1990.

12. CHENG, J.C., GUO, X., LAW, L.P., LEE, K.M., CHOW, D.H., ROSIER, R. How does recombinant human bone morphogenetic protein-4 enhance posterior spinal fusion? Spine, v.27, n.5, p.467474, Mar. 2002.

13. DAElemANS, P., HeRMANS, M., GODET, F., MALEVEZ, C. Autologous bone graft to augment the maxillary sinus in conjunction with immediate endosseous implants: a retrospective study up to 5 years. Int J Periodont Rest Dent, v.17, n.1, p.27-39, 1997.

14. DE LEONARDIS, D., PECORA, G.E. Augmentation of the maxillary sinus with calcium sulphate: one year clinical report from a prospective longitudinal study. Int J Oral Maxillofac Implants, v.14, p.869-878, 1999.

15. DUCHEYNE, P.; QIU, Q. Bioactive ceramics: the effect of surface reactivity on bone formation and bone cell function. Biomaterials, v.20, p.2287-2303, 1999.

16. FREDERIKSEN, N.L. Specialized Radiographic techniques. In: WHITE, S.C., PHAROAH, M.J. Oral Radiology: Principles and 
Interpretation. Fifth Edition. Ed. Mosby. 2003. Chapter 13 Pg 25055.

17. FROUM, S.J., TARNOW, D.P., WALLACE, S.S., ROHRER, M.D., $\mathrm{CHO}$, S.C. Sinus floor elevation using anorganic bovine bone matrix (OsteoGraf/N) with and without autogenous bone: a clinical, histologic, radiographic, and histomorphometric analysis--Part 2 of an ongoing prospective study. Int J Periodontics Restorative Dent,v.18, n.6, p.528-43, Dec 1998.

18. FUGAZZOTTO, P.A., VLASSIS, J. Long-term success of sinus augmentation using various surgical approaches and grafting materials. Int J Oral Maxillofac Implants, v.13, n.1, p.52-58, 1998.

19. FURST, G., GRUBER, R., TANGL, S., ZECHNER, W., HASS, R., MAILATH, G., SANROMAN, F., WATZEK, G. Sinus grafting with autogenous platelet-rich plasma and bovine hydroxyapatite. A histomorphometric study in minipigs. Clin Oral Implants Res, v.14, n.4, p.500-508, 2003.

20. HALLMAN, M., NORDIN, T. Sinus floor augmentation with bovine hydroxyapatite mixed with fibrin glue and later placement of non submerged implants: a retrospective study in 50 patients. Int $\mathbf{J}$ Oral Maxillofac Implants, v.19, n.2, p.222-7, 2004.

21. HALLMAN, M., SENNERBY, L., LUNDGREN, S. A clinical and histologic evaluation of implant integration in the posterior maxilla after sinus floor augmentation with autogenous bone, bovine hydroxyapatite, or a 20:80 mixture. Int J Oral Maxillofac Implants, v.17, n.5, p.635-643, Sept-Oct 2002.

22. HANISCH, O., LOZADA, J.L., HOLMES, R.E., CALHOUN, C.J., KAN, J.Y.K., SPIEKERMANN, H. Maxillary sinus augmentation prior to placement of endosseous implants: a histomorphometric analysis. Int J Oral Maxillofac Implants, v.14, n.3, p.329-336, 1999.

23. HASS, R., BARON, M., DONATH, K., ZECHNER, W., WATZEK, G. Porous hydryapatite for grafting the maxillary sinus: a comparative 
histomorphometric study in sheep. Int J Oral Maxillofac Implants, v.17, n.3, p.337-346, May-June 2002.

24. HASS, R., DONATH, K., FÖDINGER, M., WATZEK, G. Bovine hydroyapatite for maxillary sinus grafting: comparative histomorphometric findings in sheep. Clin Oral Implants Res, v.9, n.2, p.107-116, Apr. 1998.

25. HUNT, D.R., JOVANOVIC, A.S. Autogenous bone harvesting: a chin graft technique for particulate and monocortical bone blocks. Int J Periodont Rest Dent, v. 19, n. 2, p. 165-173, 1999.

26. HURZELER, M.B., QUINONES, C.R., KIRSCH, A., GLOKER, C., SCHUPBACH, P., STRUB, J.R., CAFFESSE, R.G. Maxillary sinus augmentation using different grafting materials and dental implants in monkeys. Part I. Evaluation of anorganic bovine-derived bone matrix. Clin Oral Implants Res, v.8, n.6, p.476-86, Dec. 1997.

27. INDOVINA, A, JR, BLOCK, M.S. Comparison of 3 bone substitutes in canine extraction sites. J Oral Maxillofac Surg. v.60, n.1, p.53-8, Jan. 2002.

28. JOHANSSON, B., GREPE, A., WANNFORS, K., HIRSCH, J-M. A clinical study of changes in the volume of bone grafts in the atrophic maxilla. Dentomaxillofac Radiol, v.30, n.3, p.157-161, May 2001.

29. JOHN, H, WENZ, B. Histomorphometric analysis of natural bone mineral for maxillary sinus augmentation. Int $\mathbf{J}$ Oral Maxillofac Implants, v.19, n.2, p.199-207, 2004.

30. JOSHI, A. An investigation of pos-operative morbidity following chin graft surgery. Br Dent J, v.196, n.4, p.215-218, Feb. 2004.

31. KIRKER-HEAD, C.A., NEVINS, M., PALMER, R., NEVINS, M.L., SCHELLING, S.H. A new animal model for maxillary sinus floor augmentation: elevation parameters. Int J Oral Maxillofac Implants, v.12, n.3, p.403-411, 1997.

32. LANE, J.M. Bone Graft Substitutes. West J Med, v.163, n.6, p.565566, Dec. 1995. 
33. LE GEROS, R. Z. ET AL. Calcium phosphate biomaterials: preparation, properties and biodegradations. In: Encyclopedic Handbook Of Biomaterials Anal, v.1, part A, Ed. Marcel, Dekka, N.Y., pp.1429-1463, 1995.

34. LI, R.H.; WOZNEY, J.M. Delivering on the promise of bone morphogenetic proteins. Trends in Biotechnology, v.19, n.7, July 2001

35. LINDSEY, W.H. Osseous tissue engineering with gene therapy for facial bone reconstruction. Laryngoscope; v. 111, n. 7, p. 11281136, 2001.

36. LUNA, L.G. Manual of histologic staining methods of the Armed Forces. Institute of pathology. 38 ed. New York, McGraw-Hill Book Company, p.36-38, 1968.

37. LUNDGREN, S., MOY, P., JOHANSSON, C., NILSSON, H. Augmentation of the maxillary sinus floor with particulated mandible: a histologic and histomorphometric study. Int $\mathbf{J}$ Oral Maxillofac Implants, v.11, n.6, p.760-66, Nov.-Dec. 1996.

38. MANGANO, C., BARTOLUCCI, E.G., MAZZOCCO, C. A new porous hydroxyapatite for promotion of bone regeneration in maxillary sinus augmentation: clinical and histologic study in humans. Int $\mathbf{J}$ Oral Maxillofac Implants, v.18, n.1, p.23-30, 2003.

39. MARINS, L.V., CESTARI, T.M., SOTTOVIA, A.D., GRANJEIRO, J.M., TAGA, R. Estudo radiográfico e histológico do reparo de defeito ósseo perene em calvária de rato após o tratamento com material de enxerto orgânico bovino poroso. J Appl Oral Sci, v.12, n.1, jan./mar. 2004.

40. MCCARTHY, C., PATEL, R.R., WRAGG, P.F., BROOK, I.M. Sinus augmentation bone grafts for the provision of dental implants: report of clinical outcome. Int J Oral Maxillofac Implants, v.18, n.3, p.377-382, May-June. 2003

41. MISCH, C.E.; DIETSH, F. Bone graft materials in implant dentistry. Implant Dent, v. 2, n. 3, 1993. 
42. MORSE, A. Formic acid-sodium citrate decalcification and butyl alcohol dehydration of teeth and bone sectioning in paraffin. $\mathbf{J}$ Dent Res, v. 24, n.3-4, p. 143-53, 1945.

43. NEVINS, M., KIRKER-HEAD, C., NEVINS, M., WOZNEY, J.A., PALMER, R., GRAHAM, D. Bone formation in the goat maxillary sinus induced by absorbable collagen sponge implants impregnated with recombinant human bone morphogenetic protein-2. Int J Periodontics Restorative Dent, v.16, n.1, p.9-19, 1996.

44. OLIVEIRA, R.C., SICCA, C.M., SILVA, T.L., CESTARI, T.M., KINA, J.R., OLIVEIRA, D.T., BUZALAF, M.A.R., TAGA, R., TAGA, E.M., GRANJEIRO, J.M. Avaliação histológica e bioquímica da resposta celular ao enxerto de osso cortical bovino previamente submetido a altas temperaturas. Efeito da temperatura no preparo de enxerto xenógeno. Rev Bras Ortop, v.38, n.9, p.551-560, set. 2003..

45. OLIVEIRA; R.C., SICCA; C. M., SILVA; T. L., CESTARI; T. M., OLIVEIRA; D. T., BUZALAF; M. A. R., TAGA; R., TAGA; E. M., GRANJEIRO, J.M. Efeito da temperatura da desproteinização no preparo de osso cortical bovino microgranular. avaliação microscópica e bioquímica da resposta celular em subcutâneo de ratos. Rev Fac Odontol Bauru, v. 7, n. 3/4, p. 85-93, jul./dez. 1999.

46. OLSON, J.W., DENT, C.D., MORRIS, H.F., OCHI, S. Long term assessment (5 to 71 months) of endosseous dental implants placed in the augmented maxillary sinus. Ann Periodontol, v.5, n.1, p.152-156, Dec. 2000.

47. OREFFO, R.O.C.; TRIFFIT, J.T. Future potencials for using osteogenic stem cells and biomaterials in orthopedics. Bone, v. 25, n. 2, Aug 1999. 5S-9S.

48. PEETZ, M. Characterization of xenogenic bone material. In: Boyne, P.J. Osseous reconstruction of the maxilla and the mandible surgical techniques using titanium mesh and bone mineral. 
p.87-100. Chicago, Berlin: Quintessence. 1997.

49. PIATTElli, M., FAVERO, G. A., SCARANO, A., ORSINI, G., PIATTELLI, A. Bone reactions to anorganic bovine bone (Bio-Oss) used in sinus augmentation procedures: a histologic long-term report of 20 cases in humans. Int J Oral Maxillofac Implants, v.14, n.6, p.835-840, Nov.-Dec. 1999.

50. PRUSS, A., SEIBOLD, M., BENEDIX, F., FROMMELT, L., VON GARREL, T., GURTLER, L., DORFFEL, Y., PAULI, G., GOBEL, U. B. Validation of the 'Marburg bone bank system' for thermodisinfection of allogenic femoral head transplants using selected bacteria, fungi, and spores. Biologicals, v.31, n.4, p.28794, Dec. 2003.

51. RAGHOEBAR, G.M., BROUWER, T.J., REINTSEMA, H., VAN OORT, R.P. Augmentation of the maxillary sinus floor with autogenous bone for the placement of endosseous implants: a preliminary report. J Oral Maxillofac Surg, v.51, n.11, p.1198-1203, Nov. 1993.

52. RAGHOEBAR, G.M., LOUWERSE, C., KALK, W.W.I., VISSINK, A. Morbidity of chin bone harvesting. Clin Oral Implant Res, v.12, n.5, p.503-507, Oct 2001.

53. REDDI, A.H. Bone morphogenetic proteins: from basic science to clinical applications. J Bone Joint Surg Am, v.83-A, p.1-6, 2001. Supplement 1.

54. SCHIMMING, R., SCHELZEISEN, R. Tissue-engineered bone for maxillary sinus augmentation. J Oral Maxillofac Surg, v.62, n.6, p.724-729, June 2004.

55. SCHLEGEL, K.A., FICHTNER, G., SCHULTZE-MOSGAU, S., WILTFANG, J. Histologic findings in sinus augmentation with autogenous bone chips versus a bovine bone substitute. Int $\mathbf{J}$ Oral Maxillofac Implants, v.18, n.1, p.53-58, 2003.

56. SCHMELZEISEN, R., SCHIMMING, R., SITTINGER, M. Making bone: implant insertion into tissue-engineered bone for maxillary sinus 
floor augmentation-a preliminary report. J Craniomaxillofac Surg, v.31, n.1, p.34-9, 2003.

57. SCHULTZE-MOSGAU, S., KEWELOH, M., WILTFANG, J., KESSLER, P., NEUKAM, F.W. Histomorphometric and densitometric changes in bone volume and structure after avascular bone grafting in the extremely atrophic maxilla. $\mathrm{Br} \mathbf{J}$ Oral Maxillofac Surg, v.39, p.439-447, Feb. 2001.

58. SERVICE, R.F. Tissue engineering build new bone. Science, v. 289, p.1497-1514, Sept. 2000.

59. SICCA, C.M., OLIVEIRA, R.C., SILVA, T.L., CESTARI, T.M., OLIVEIRA, D.T., BUZALAF, M.A., TAGA, R., TAGA, E.M., KINA, J.R., GRANJEIRO, J.M. Avaliação microscópica e bioquímica da resposta celular a enxertos de osso cortical bovino em subcutâneo de ratos. efeito do tamanho da partícula. Rev Fac Odontol Bauru, v. 8, n. 1/2, p. 1-10, jan/jun. 2000.

60. STEPHAN, E.B. Anorganic bovine bone supports osteoblastic cell. attachment and proliferation. J Periodontol, v.70, n.4, p.364-9, 1999.

61. SZILVASSY, S.J. Boning up on tissue engineering. Tibtech, v.18, n.12, p.482, Dec. 2000.

62. TADJOEDIN, E.S., DE LANGE, G.L., LYARUU, D.M., KUIPER, L., BURGER, E.H. High concentrations of bioactive glass material (Bio-Gran $®$ ) vs. autogenous bone for sinus floor elevation. Histomorphometrical observations on the three split mouth clinical cases. Clin Oral Implant Res,v.13, n.4, p.428-436, Aug. 2002.

63. TAGA, E.M. Biomateriais para uso em clínica médico-odontológica. Rev Bras Cir Implant, v. 3, n.1, p. 59-69, jul/ago 1996.

64. TAGA, R., CESTARI, T.M.; SILVA, T.L.; STIPP, A.C.M. Reparo de defeito ósseo perene em crânio de cobaia pela aplicação de osseobond. Rev Bras Implant, v.3, n.1, p.13-20, jan/fev 1997.

65. TAYLOR, J.C., CUFF, S.E., LEGER, J.P., MORRA, A., ANDERSON, G.I. In vitro osteoclast resorption of bone substitute biomaterials 
used for implant site augmentation: a pilot study. Int Oral Maxillofac Implants, v.17, n.3, p.321-330, 2002.

66. TERHEYDEN, H., JEPSEN, S., MÖLleR, M. M., RUEGER, D. C. Sinus floor augmentation with simultaneous placement using a combination of a deproteinized bone xenografts and recombinant human osteogenic protein-1. A histometric study in miniature pigs. Clin Oral Implant Res, v.10, n.6, p.510-21, Dec. 1999.

67. TONG, D.C., RIOUX, K., DRANGSHOLT, M., BEIRNEM, O.R. A review of survival rates for implants placed in grafted maxillary sinuses using meta-analysis. Int $\mathbf{J}$ Oral and Maxillofac Implants; v.13, n.2, p.175-182, Mar.-Apr. 1998.

68. UEDA, M., TOHNAI, I., NAKAI, H. Tissue engineering research in oral implant surgery. Artif Organs, v.25, n.3, p.164-171, 2001.

69. URIST, M.R. Bone: formation by autoinduction. Science, v. 150, n. 698, p. 893-99, 1965.

70. URIST, M.R., LIETZE, A., DAWSON, E. Beta-tricalcium phosphate delivery system for bone morphogenetic protein. Clin Orthop, v.187, p.277-80, Jul-Aug. 1984.

71. URIST, M.R.; STRATES, E.S. Bone formation in implants of partially and wholly demineralized bone matrix. Clin Orthop, v.70, n.71, p.271-78, 1970.

72. VALENTINI, P., ABENSUR, D.J. Maxillary sinus grafting with anorganic bovine bone: a clinical report of long-term results. Int $\mathbf{J}$ Oral Maxillofac Implants, v.18, n.4, p.556-560, 2003.

73. VAN DEN BERGH, J.P., TEN BRUGGENKATE, C.M., GROENEVELD, H.H., BURGER, E.H., TUINZING, D.B. Recombinant human bone morphogenetic protein-7 in maxillary sinus floor elevation surgery in 3 patients compared to autogenous bone grafts: a clinical pilot study. J Clin Periodontol, v.27, n.9, p.627-36, Sept. 2000.

74. VAN DEN BERGH, J.P.A., TEN BRUGGENKATE, C.M., DISCH, F.J.M., TUINZING, D.B. Anatomical aspects of sinus floor 
elevations. Clin Oral Implant Res, v.11, n.3, p.256-65, June 2000.

75. VAN DEN BERGH, J.P.A., TEN BRUGGENKATE, C.M., KREKELER, G., TUINZING, D.B., Maxillary sinus floor elevation and grafting with human demineralized freeze dried bone. Clin Oral Implant Res, v.11, p.487-493, 2000.

76. VIANA, R.I. Estudo comparativo entre a hidroxiapatita reabsorvível e hidroxiapatita reabsorvível conjugada ao pool de BMPs. Análise morfológica e atividade fosfatase ácida em fibroblasto de mucosa humana (linhagem FMM1). Campinas, 2003. 100p. Instituto de Biologia Estrutural e Funcional Universidade Estadual de Campinas

77. WADA, K., NIIMI, A., WATANABE, K., SAWAI, T., UEDA, M. Maxillary sinus floor augmentation in rabbits: a comparative histologichistomorphometric study between rhBMP-2 and autogenous bone. Int J Periodontics Restorative Dent, v.21, n.3, June 2001.

78. WALLACE, S.S., FROUM, S.J. Effect of maxillary sinus augmentation on the survival for endosseous dental implants: a systematic review. Ann Periodontol, v.8, n.1, p.328-43, 2003.

79. WATANABE, K.; NIIMI, A.; UEDA, M. Autogenous bone grafts in the rabbit maxillary sinus. Oral Surg Oral Med Oral Pathol Oral Radiol Endod, v. 88, n.1, p. 26-32, July 1999.

80. WEIBEL, E. R. Stereological principles for morphometry in electron microscopic cytology. Int Rev Cytol, v.26, p.235-302, 1969.

81. WILTFANG, J., SCHELEGEL, K.A., SHULTZE-MOSGAU, S., NKENKE, E., ZIMMERMAN, R., KESSLER, P. Sinus floor augmentation with ß-tricalcium phosphate (B-TCP): Does plateletrich plasma promote its osseous integration and degradation? Clin Oral Implant Res, v.14, n.2, p.213-218, Apr. 2003.

82. $\mathrm{XU}, \mathrm{H}$., SHIMIZU, Y., ASAI, S., OOYA, K. Experimental sinus grafting with the use of deproteinized bone particles of different sizes. Clin Oral Implant Res, v.14, n.5, p.548-55, Oct. 2003.

83. XU, H., SHIMIZU, Y., ASAI, S., OOYA, K. Grafting of deproteinized 
bone particles inhibits bone resorption after maxillary sinus floor elevation. Clin Oral Implant Res, v.15, n.1, p.126-133, Feb. 2004.

84. XU, H., SHIMIZU, Y., ONODERA, K., OOYA, K. Long-term outcome of augmentation of the maxillary sinus using deproteinized bone particles experimental study in rabbits. Br J Oral Maxillofac Surg, v.43, n.1, p.40-5, Feb. 2005.

85. YILDIRIM M., SPIEKERMANN, H., BIESTERFELD, S., EDELHOFF, D. Maxillary sinus augmentation using xenogenic bone substitute material Bio-Oss $₫$ in combination of venous blood. A histologic and histomorphometric study in humans. Clin Oral Implant Res, v.11, n.3, p.217-229, June 2000.

86. YILDIRIM, M., SPIEKERMANN, H., HANDT, S., EDELHOFF, D. Maxillary sinus augmentation with the xenograft Bio-Oss and autogenous intraoral bone for qualitative improvement of the implant site: a histologic and histomorphometric clinical study in humans. Int J Oral Maxillofac Implants, v.16, n.1, p.23-33, JanFeb 2001.

87. YOSHIKAWA, T., OHGUSHI, H., ICHIJIMA, K., TAKAKURA, Y. Bone regeneration by grafting of cultured human bone. Tissue Eng, v.10, n.5-6, p.688-98, May-Jun 2004.

88. YOUNGER, E.M., CHAPMAN, M.W. Morbidity at bonegraft donor sites. J Orthop Trauma, v.3, n.3, p.192-195, 1989.

89. YUKNA, R.A. ET AL. Multi-center clinical evaluation of combination anorganic bovine-derived ha matrix $(\mathrm{abm}) /$ cell binding peptide ( $\mathrm{p}$ 15) as a bone replacement graft material in human periodontal osseous defects. 6-month results. J Periodontol, v.69, n.6, p.65563, 1998. 


\begin{abstract}
The purpose of this study was to evaluate new bone formation induced by a bovine xenograft compared to autogenous bone in maxillary sinus augmentation in rabbits. The maxillary sinus of 18 male rabbits were used, whereas the left sinus was filled with $200 \mathrm{mg}$ of a mixture of cortical and medullar autogenous bone and the right sinus was filled with a mix of organic and inorganic bovine matrix, plus "pool" of BMPs and collagen (Gen-Tech®). Computer tomography (CT) analysis was realized to evaluate and compare the optical density among the groups and experimental periods; descriptive histologic analysis was used to verify the tissue response to the materials implanted. In addition, histomorphometric analysis was realized to evaluate volume density of the newly formed bone, connective tissue and/or granulation tissue, residual material and myeloid tissue. The results obtained in the CT demonstrated an optical density approximately 2 times greater in the test groups. Histological analysis revealed an inflammatory infiltrate at 2 weeks in the test group and exclusively around the organic portion of the material. Regarding new bone formation, no statistical differences were observed among the two experimental groups or throughout the experimental periods. However the area of myeloid tissue was 2 times greater in the control group. Considering the limits of the experimental model and technique used in this study, it is possible to conclude that Gen-Tech ${ }^{\circledR}$ is a biomaterial with potential applications as a bone substitute in maxillary sinus augmentation once it is able to promote the formation of new bone similarly to autogenous bone.
\end{abstract}

